\title{
The effect of environmental decentralization on polluting firms in India
}

Article

Accepted Version

Lovo, S. (2018) The effect of environmental decentralization on polluting firms in India. Economic Development and Cultural Change, 67 (1). pp. 55-94. ISSN 1539-2988 doi: https://doi.org/10.1086/697558 Available at https://centaur.reading.ac.uk/69413/

It is advisable to refer to the publisher's version if you intend to cite from the work. See Guidance on citing.

To link to this article DOI: http://dx.doi.org/10.1086/697558

Publisher: The University of Chicago Press

All outputs in CentAUR are protected by Intellectual Property Rights law, including copyright law. Copyright and IPR is retained by the creators or other copyright holders. Terms and conditions for use of this material are defined in the End User Agreement.

\section{www.reading.ac.uk/centaur}

\section{CentAUR}

Central Archive at the University of Reading

Reading's research outputs online 


\title{
The effect of environmental decentralization on polluting firms in India.
}

\author{
Stefania Lovo \\ s.lovo@reading.ac.uk \\ Department of Economics, University of Reading
}

March 2015

\begin{abstract}
This paper examines the effects of the environmental decentralization fostered by a 2006 reform of the Environmental Impact Assessment process in India. It adopts a triple differences approach that compares treated and untreated sectors across states with different level of environmental enforcement. Results based on firm-level data for the period 1998-2012 show that the reform induced a decrease in firm births in states with stricter enforcement. The findings draw attention on the consequences of great disparities in enforcement capacity in a decentralized environment.
\end{abstract}

Keywords: Decentralization, firm births, environmental enforcement, India.

JEL: O14, Q58

\section{Introduction}

The decentralization of environmental regulation is often justified by the intention to make use of better understanding of local environmental problems, to promote more transparent and efficient use of natural resources and to increase local participation due to higher homogeneity of common needs (Cistulli, 2002). There are, however, well recognized constrains on the successfulness of any decentralization process such as weak administrative or technical capacity, lack of financial resources, poor coordination between national and local policies and the risk of local elite capture. In addition to these trade-offs, spillovers and heterogeneity across localities are crucial in influencing the overall impact of decentralization (Besley and Coate, 2003).

The author would like to thank Hendrik Wolff, Teevrat Garg, Matt Khan, Phoebe Koundouri and the two anonymous referees of this journal for the very helpful comments and suggestions. This research was partially conducted as part of the green growth programme at the Grantham Research Institute on Climate Change and the Environment at the London School of Economics and Political Science, which was funded by the Global Green Growth Institute, as well as the Grantham Foundation for the Protection of the Environment, and the Economic and Social Research Council through the Centre for Climate Change Economics and Policy. 
In India, environmental standards are decided by the central government but a large part of environmental compliance, monitoring and enforcement is responsibility of state-level Pollution Control Boards (SPCB). This paper examines the effects of further decentralization of environmental decision-making on the birth of polluting firms. All registered polluting firms in India are subject to an Environmental Impact Assessment (EIA). Environmental clearance is necessary for a firm to start operating and determines what pollution control measures should be maintained operative. A 2006 reform of the EIA process delegated the responsibility over environmental clearance of certain activities, previously under the control of the central government, to newly established state-level authorities. The reform, therefore, introduced a new source of variation in entry costs due to differences in the stringency of the EIA across states. Because environmental enforcement has been found to vary notably across states, possibly due to variations in socio-economic and political conditions but also due to state-specific technical and financial constraints (Nandimath, 2009), differences in compliance costs could be large and are expected to affect entry decisions and, ultimately, the distribution of new polluting firms across states.

While the relationship between decentralized environmental regulation and firms' behavior in developed countries, and in particular in the US, has been investigated is several studies, there is very little empirical evidence on developing countries. Developing countries differ substantially from more advanced economies. Not only do they face greater trade-offs between the gains from industrial growth and the related environmental costs but also institutions are substantially different and political economy factors and market failures greatly affect policy making and outcomes (Greenstone and Jack, 2015). This paper contributes to the field by investigating the impact of the 2006 EIA reform that introduced further decentralized environmental regulation in India and examines whether differences in enforcement capacity across states had produced heterogeneous effects on the birth of polluting firms.

The empirical strategy exploits the reform design that assigns only certain polluting activities to decentralized authorities (treated sectors), while for others the assessment remains centralized (untreated sectors). The identification strategy is based on comparing pre- and post-reform patterns of firm births, conditional on the strength of environmental enforcement, between treated and untreated sectors. The inspection of a long series of pre-reform firm births shows that the common trends assumption underlying this triple differences approach holds in the data. Enforcement capacity at the state level is measured using a composite index obtained by aggregating various state-level indicators of institutional quality, civic participation and institutional capacity. The estimations are based on the population of registered firms born during the period 1998-2012. Although the formal sector contributes to only a small fraction of total Indian output, only registered firms are subject to environmental clearance since smaller informal firms tend to operate outside the control of pollution control authorities.

A first assessment of the raw data shows a striking difference in the patterns of firm births between high and low enforcing states in the post-reform period for treated sectors. Regression results confirm the negative impact of state-level enforcement on firm births after the reform, while show no impact for untreated sectors. These findings are associated with an economically relevant slowdown in births of polluting firms close to a $12 \%$ reduction. The effect is consistent with an increase in average regulatory stringency driven by states with higher levels of enforcement that tend to be larger, richer, and more developed. A more disaggregated analysis confirms that the estimated decrease in the number of new registered firms can be most likely attributed to an actual reduction in polluting firms rather than a switch to informality. The remainder of the paper is organized as follows. Section 2 provides a brief overview of the relevant literature on environmental decentralization and firm location. Section 3 describes the 
policy background and the reform of the EIA process introduced in 2006. The empirical model is presented in section 6 while the data on firm births and environmental enforcement are described in section 4. Section 5 and 7 present the empirical findings and provide support for the validity of the identification strategy. Section 8 provides an economic quantification of the impact of the reform and discusses policy implications. Finally, section 9 concludes.

\section{Decentralization, environmental regulation and firm location}

The empirical literature on the impact of environmental decentralization on firms' behavior has mainly focused on developed countries. Brunnermeier and Levinson (2004) review this literature and find that while earlier cross sectional studies tend to find no significant effect of environmental regulation on firms' decisions, more recent studies that use panel data estimations find evidence of firms responding to variations in regulation within a country. Many empirical studies focus on variations in regulation across counties and states of the United States (List et al., 2003). Becker and Henderson (2000), for example, study variations in air quality regulation across counties and find that there has been a significant relocation of polluting firms from more to less regulated areas. Sigman (2005) shows that the decentralization of environmental authorities in the United States has led to a $4 \%$ increase in water degradation downstream of states that had the authority to issue and enforce permits for point source polluters. Very few studies have focused on the impact of environmental decentralization in developing countries. Duvivier and Xiong (2013), for example, studies trans-boundary pollution in China where environmental policy is decentralized. Similarly to India, while the central government sets the standards, local governments are in charge of monitoring and sanctioning. The authors analyze the location choice of polluting firms in one of the most polluted provinces in China and find that polluting firms tend to locate in counties that share a border with another province. Similarly, Lipscomb and Mobarak (2016) analyze river water quality across jurisdictions in Brazil and find a significant strategic polluting behavior around borders.

The first study to analyze firms' location decisions in response to differential environmental regulation across Indian states was conducted by Mani et al. (1997). The study finds that the number of new plants is not affected by the differences in stringency of environmental regulation at the state level. A positive correlation between their measure of enforcement and the number of new plants, however, suggests that the variable might be capturing the quality of state government rather than environmental enforcement. Moreover, the data date back to 1994 when there was very little enforcement of environmental regulation across all states since prosecution could only occur through the judicial system (Lipscomb, 2008). There is, however, evidence of Indian firms adjusting their behavior in response to changes in environmental regulation over time. Lipscomb (2008), for example, analyses the response of multi-product firms to changes in enforcement at the state level. The author finds that firms react to increased stringency by increasing the share of the product portfolio allocated to clean products. High productivity firms invest in new and cleaner products and gain from an increase in enforcement. Kathuria (2007) finds that an increase in informal regulation, measured by local news coverage of pollution-related events and the number of public interest litigations filed, has reduced industrial pollution in the state of Gujarat. On the other hand, however, formal regulation, measured by the number of staff allocated to a state, was found not to affect polluting behavior. Issues surrounding environmental monitoring and compliance in India have also been investigated in Duflo et al. (2013) who look into environmental audits of industrial plants and the frequency of environmental inspections in Gujarat. Finally, besides firm behavior, differences in the effectiveness of air and water pollution 
regulations across cities in India have also been found to affect health outcomes such as infant mortality (Greenstone and Hanna, 2014).

\section{Environmental policies in India}

Environmental protection rights and duties are incorporated into the Indian Constitution. India has an elaborate set of laws relating to environmental protection that dates back to the Water Act in 1974. The central government, through the Ministry of Environment and Forests (MOEF) and the Central Pollution Control Board (CPCB), is in charge of planning and formulating national policies and standards. Their implementation and enforcement are decentralized and are the responsibility of the State Pollution Control Boards.

In addition, Indian citizens benefit from a unique approach to the enforcement of environmental laws by exercising their constitutional right to a healthy environment in the form of Public Interest Litigations (PILs) before the Court of Justice. PILs have resulted in some environmental improvements on the one side, (Kathuria, 2007) but have also contributed to increase the amount of work for state authorities because of court-ordered directives (OECD, 2006).

A compulsory Environmental Impact Assessment (EIA) was first introduced in India with the Environmental Protection Act of 1986, but became effective only in 1994 when the MOEF passed a major legislative measure (Panigrahi and Amirapu, 2012). The main purpose of the EIA is to inform decision makers and the public about the environmental implications of a particular project. The EIA process has been notably modified with the introduction of the 2006 EIA notification. In particular, the reform introduced two main changes. It put greater emphasis on public participation, through a formal consultation procedure for all firms, and initiated a process of decentralization of the EIA procedure for certain activities. While both changes have the potential to affect firm behavior, this paper focuses on the latter due to methodological constraints that are explained below. The decentralization process has the potential to reduce the burden on the central government and accelerate the approval process. On the other hand, however, the newly created decentralized powers could be misused, if state governments intend to actively pursue industrialization for their respective state, or be ineffective if state authorities lack technical and financial capacity.

For the purpose of assigning polluting projects to the competent authority, the reform classifies projects into two categories based on the potential impacts on human health and natural resources. Projects falling into category A continue to undertake the EIA at the national level (the untreated group), while category B projects are referred to the State Environmental Impact Assessment Authority (SEIAA) of the state in which the project is located and form the treatment group. The classification of projects into treated (B) and untreated (A) activities is based on three main criteria that differ across sectors: type of activity, capacity and location. Because the data used in the analysis do not allow for the identification of the capacity or the exact location of a project, sectors adopting these criteria are considered to include both treated and untreated firms. Therefore, in the analysis that follows sectors are categorized into 5 different groups as described in Table 1. The first group includes sectors that do not have to undertake the EIA since they are not expected to have a considerable impact on the environment. The second and last group (2 and 5) adopt the "activity" criterion that assigns projects to either a state or a central authority based on the type of activity. Any project within the petroleum refining industry (sector 232 in the Table), for instance, should undertake the EIA at the central level, while projects in the integrated paint industry (2422 in the table), are the exclusive responsibility of state authorities. This allows to define the group "Central" composed of firms in sectors 
Table 1: Classification of sectors according to EIA status

\begin{tabular}{|c|c|c|c|c|}
\hline$\#$ & Treatment Group & Category & Criteria & Sectors (NIC) \\
\hline 1 & No EIA & No EIA & $\begin{array}{l}\text { Not subject to EIA } \\
\text { (control) }\end{array}$ & $\begin{array}{l}\text { All sectors not indi- } \\
\text { cated below }\end{array}$ \\
\hline 2 & Central & $\mathrm{A}$ & $\begin{array}{lr}\text { Activity subject } & \text { to } \\
\text { central-level } & \text { EIA } \\
\text { (untreated) } & \end{array}$ & $\begin{array}{l}111,112,232,233, \\
269,2412,2421\end{array}$ \\
\hline 3 & Capacity & $\mathrm{A} / \mathrm{B}$ & $\begin{array}{l}\text { State-level EIA if of } \\
\text { small capacity (mix } \\
\text { treated/untreated) }\end{array}$ & 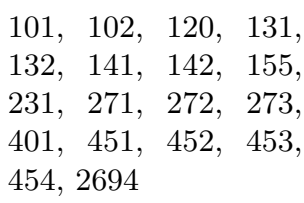 \\
\hline 4 & ID & $\mathrm{A} / \mathrm{B}$ & $\begin{array}{l}\text { State-level EIA if located } \\
\text { within industrial district } \\
\text { (mix treated/untreated) }\end{array}$ & $\begin{array}{l}182, \quad 1911 \\
2413,2423\end{array}$ \\
\hline 5 & State & $\mathrm{B}$ & $\begin{array}{l}\text { Activity subject to state- } \\
\text { level EIA } \quad \text { (treated) }\end{array}$ & $\begin{array}{l}1542,2101^{a}, 2102, \\
2422,2430\end{array}$ \\
\hline
\end{tabular}

Based on NIC (Indian National Industrial Classification) 2004. ${ }^{a}$ Excludes manufacturing of pulp (21011)

unaffected by the decentralization reform (untreated) and the group "State" formed of firms affected by the reform (treatment group). A second criterion distinguishes projects in terms of capacity (group 3). Large coke oven plants (above 150,000 tons per year, 231 in the Table), for example, are under the authority of the central government, small ones are referred to the SEIAA in which the project is located. Because the data used in the empirical analysis do not include information on firms' capacity, it is not possible to distinguish between treated and untreated firms and the group "Capacity" includes a mix of both. An attempt to separate treated and untreated firms will be made using firm size as a proxy for capacity in section 7.1. Finally, a third criterion categorizes projects on the basis of whether they are located within or outside a notified industrial area (group 4). Projects in the leather/skin/hide processing industry (1911 in the Table), for example, are subject to state level EIA only if located within an industrial district/area. Because the exact location of a firm is unknown, the group defined as "Industrial district (ID)" includes both treated and untreated firms.

Table 1 summarizes the five different groups of activities defined in accordance to the criteria mentioned above. The detailed list of activities, as reported in the official 2006 EIA notification, is provided in Table A.1 of the Appendix. SEIAAs were constituted in each state at different points in time and all projects were treated as category $\mathrm{A}$ in the absence of a notified state authority. Table A.2 of the Appendix reports the date of establishment of each SEIAA.

The EIA process is subdivided into four stages. The first stage (Screening) affects only category B projects and is aimed at determining whether a project requires an EIA report. Projects requiring EIA are categorized as B1 while the others are termed B2 and submit a much shorter application form. The remaining steps apply to both categories of projects. The second stage (Scoping) involves either the central or state authority, depending on whether the project is classified as A or $\mathrm{B}$, in determining the terms of references covering all relevant environmental concerns for the preparation of the EIA. The third stage requires a public consultation through both a public hearing in the proximity of the site and invitations of written responses from the concerned 
stakeholders. The final stage (Appraisal) involves the scrutiny of the EIA application that can result in either approval or $\mathrm{r} E_{j}$ ection of the project. Environmental clearance is granted by the Ministry of Environment and Forests for type A projects and by the SEIAA for type B projects.

\section{Data}

This section describes the data used to measure environmental enforcement across states and the firm-level data used to analyze the relationship between the EIA reform and firm births.

\subsection{State-level environmental enforcement measures}

Although environmental standards for industrial pollution are determined by the central government, evidence suggests that there are large differences across states in terms of enforcement and compliance (OECD (2006); World Bank (2006)). Variations arise from socio-economic differences across states but also from differences in commitment and technical and financial capacity of state-level environmental authorities. The analysis uses five measures of environmental enforcement aimed at capturing state-level differences in institutional capacity, civic participation and institutional quality that are reported in Table 2 . The choice of the specific indicators was partly driven by data availability.

Institutional capacity is measured by the number of air monitoring stations. The data, taken from the IndiaStat database, refer to the year 2007 and reveal a significant variation across states, ranging from 2 in Bihar, Meghalaya and Uttarakhand to 42 in Maharashtra.

When formal regulation is weak, informal regulation through civic participation can play an important role. This is particularly true in India where a democratic system allows the formation of groups and NGOs, the press is relatively free and people are empowered with the use of public interest litigations to demand interventions of the judiciary system. These features are particularly relevant for this study since citizens are given an active role in the EIA procedure through a public hearing stage. Three measures of civic participation are adopted: the number of environmentally oriented NGOs, the number of newspaper articles mentioning environmental-related news and the number of judgments passed by the supreme and high courts related to environmental disputes. While civic participation can be thought to be higher in states with low environmental compliance as a response to ineffective formal enforcement, Lal and Jha (1999) argue that NGOs and greater judicial effort are more likely found in Indian states with good governance indicating that strong governance is more conducive to building public awareness about the environment. This argument supports the use of these variables as indicators of greater environmental enforcement.

NGOs play an important role in shaping the socio-political discourse in India and there are several examples of how these organizations have successfully promoted environmental disclosure and raised awareness of governments and the general public (UNESCAP, 2000) ${ }^{1}$. The number of environmentally oriented NGOs was also used in Javorcik and Wei (2003) to measure variation in strength of environmental enforcement across countries. Another measure of public concern over environmental issues is represented by the number of newspaper articles covering topics related to industrial pollution. The number of newspaper articles in each state and year was obtained by conducting a search across all English-language Indian newspapers contained in the database Factiva for the period 1998-2006. Each search included a set of common keywords, such as closure, court, order, fine etc., and the name of the State Pollution Control Board, e.g. Bihar

\footnotetext{
${ }^{1}$ The list of Indian NGOs was obtained from an online database: http://ngosindia.com/ accessed in June 2013.
} 
Table 2: Environmental enforcement measures and construction of the enforcement index

\begin{tabular}{|c|c|c|c|c|c|c|}
\hline State & $\begin{array}{c}\text { NGOs } \\
2013\end{array}$ & $\begin{array}{c}\text { Judgements } \\
1998-2006\end{array}$ & $\begin{array}{c}\text { Corruption } \\
2005\end{array}$ & $\begin{array}{c}\text { Articles } \\
1998-2007\end{array}$ & $\begin{array}{c}\text { Stations } \\
2007\end{array}$ & Index \\
\hline Andhra Pradesh & 29 & 4 & 4 & 213 & 21 & 2.50 \\
\hline Assam & 7 & 0 & 15 & 9 & 12 & -1.55 \\
\hline Bihar & 2 & 3 & 20 & 13 & 2 & -1.63 \\
\hline Chandigarh & 2 & 2 & & 4 & 5 & \\
\hline Chhattisgarh & 3 & 0 & 6 & 4 & 9 & -1.60 \\
\hline Delhi & 22 & 2 & 11 & 166 & 11 & 0.59 \\
\hline Goa & 0 & 0 & & 13 & 3 & \\
\hline Gujarat & 7 & 4 & 3 & 146 & 20 & 0.99 \\
\hline Haryana & 3 & 1 & 13 & 21 & 5 & -1.71 \\
\hline Himachal Pradesh & 4 & 2 & 2 & 3 & 11 & -0.72 \\
\hline Jammu \& Kashmir & 6 & 0 & 19 & 3 & 3 & -2.22 \\
\hline Jharkhand & 2 & 0 & 14 & 5 & 6 & -2.10 \\
\hline Karnataka & 17 & 3 & 17 & 247 & 14 & 0.83 \\
\hline Kerala & 7 & 0 & 1 & 155 & 16 & -0.25 \\
\hline Madhya Pradesh & 12 & 4 & 18 & 43 & 26 & 0.59 \\
\hline Maharashtra & 26 & 4 & 5 & 165 & 42 & 3.13 \\
\hline Meghalaya & 1 & 0 & & 0 & 2 & \\
\hline Odisha & 17 & 3 & 9 & 8 & 12 & 0.10 \\
\hline Puducherry & 1 & 0 & & 2 & 3 & \\
\hline Punjab & 1 & 1 & 7 & 25 & 15 & -1.09 \\
\hline Rajasthan & 12 & 0 & 16 & 6 & 18 & -1.03 \\
\hline Tamil Nadu & 29 & 2 & 12 & 443 & 16 & 2.28 \\
\hline Uttar Pradesh & 24 & 4 & 10 & 111 & 35 & 2.27 \\
\hline Uttarakhand & 4 & 1 & & 2 & 2 & \\
\hline West Bengal & 15 & 2 & 8 & 120 & 21 & 0.62 \\
\hline
\end{tabular}

\begin{tabular}{|c|c|c|c|}
\hline \multicolumn{4}{|c|}{ Principal Component analysis: } \\
\hline Component & Eigenvalue & Proportion of Variance & Cumulative \\
\hline Comp1 & 2.730 & 0.546 & 0.546 \\
\hline Comp2 & 0.977 & 0.195 & 0.742 \\
\hline Comp3 & 0.742 & 0.148 & 0.890 \\
\hline Comp4 & 0.384 & 0.076 & 0.967 \\
\hline Comp5 & 0.165 & 0.033 & 1.000 \\
\hline Variable & First component & & \\
\hline NGOs & 0.538 & & \\
\hline Judgments & 0.463 & & \\
\hline Corruption Index & -0.226 & & \\
\hline Total articles & 0.451 & & \\
\hline Stations & 0.491 & & \\
\hline
\end{tabular}

State Pollution Control Board. The variable is then constructed by calculating the cumulative number of articles referring to each State Pollution Control Board for the entire pre-reform period. Finally, it was noted that Indian citizens can benefit from a unique approach to enforce environmental law by exercising a constitutional right before the Supreme Court and the High Courts in the form of Public Interest Litigations (PIL). Unfortunately, it is not possible to obtain the number of PILs filed in each state, but the number of judgments of the Supreme and High courts offers a reasonable proxy. The list of judgments related to environmental issues for the period 1998-2006 is obtained from the Judgments information system of the Supreme and High courts of India. Judgments are manually assigned to each state based on the location of the firms or the pollution control boards involved in the court case.

To measure institutional quality I use the corruption index at the state-level provided in a study by the Centre for Media Studies issued by Transparency International India for the year 2005 (CMS, 2005). While this index is the preferred measure of corruption, it is not available for the Union territories of Chandigarh, Goa, Meghalaya, Puducherry and Uttarakhand that are, 
therefore excluded from part of the analysis ${ }^{2}$.

All enforcement measures are time-invariant and refer to the pre-reform period with the exception of the number of NGOs ${ }^{3}$. They are aggregated into a unique index of state-level enforcement through principal component analysis. The use of principal component analysis is appealing because the variables are correlated and environmental enforcement is a multifaceted concept that none of the indicators can fully capture. The index conveys the common dimension of the data and should, therefore, provide a better proxy of environmental enforcement than each indicator individually. The bottom part of table 2 shows that, as expected, all measures but the corruption index are positively related to the latent environmental enforcement measure. The first principal component explains about $37 \%$ of the total variance in the data. The eigenvalue of the first principal component is above two, thus I retain only the first component as enforcement index. The index ranges between -2.22 and 3.13 and takes higher values in states where environmental enforcement is stronger ${ }^{4}$. As a robustness check, I also construct an alternative enforcement index where all enforcement variables, with the exception of corruption, are divided by the size of the population. The results are reported in Table A.6, Columns 1 and 2, and show similar results.

\subsection{Firm-level data}

The number of new firms in each sector and year is obtained from the Orbis database of Bureau Van Dijk who publishes data originally provided by the Centre for Monitoring Indian Economy (CMIE). The database covers the universe of registered companies, i.e. all companies, public or private, that are registered under the Companies Act, 1956 at the Registrar of Companies (RoCs). It records about 140,000 companies created between 1998 and the end of 2012. Although registered companies account for only $20 \%$ of all firms in India, which tend to be very small and operate under informality, they are the most likely to be subject to pollution controls as only large and medium-sized facilities have the required environmental clearance permits. Most small-scale industries operate without any consent (OECD, 2006).

The analysis considers only companies belonging to the manufacturing and energy sectors. While the database provides very little information on companies characteristics, such as assets, employment etc., it was possible to obtain important information using the corporate identification number (CIN) that the Ministry of Corporation assigns to each registered company and that combines information on the year of establishment, state, 5-digit industry code (National Industrial Classification, NIC), ownership type and a registrar code. In 1998 the Indian Statistical office adopted a substantially different sector classification which also affected the sector definition contained in the CIN code. To avoid problems of misclassification of some firms, the analysis considers only firms established after 1998. This does not constitute a major drawback since prior to 1997 there was very little enforcement of environmental regulation across all states (Lipscomb, 2008).

\footnotetext{
${ }^{2}$ I also obtained the same results (not reported) using an alternative measure of institutional quality constructed as the number of cases of persons arrested under the prevention of corruption act and related sections that have obtained charges. The information is obtained from the India Bureau of Crime and was available for all states. Similar results are also obtained excluding corruption from the enforcement index.

${ }^{3}$ The use of post-reform data on NGOs' could be of potential concern. The results by individual component reported in Table 4, however, show similar results across indicators suggesting that the use of a post-reform measure of NGOs is not of particular concern.

${ }^{4}$ There are various and highly heterogeneous rules of thumbs to determine the minimum sample size for principal component analysis (Giovannini et al., 2005). Some rules suggest a minimum of 3 or 5 observations per variable. In this case, given that the analysis covers 20 states, the reliability of the index could be in doubt. To provide further support to the results I also constructed an index that gives equal weights to all standardized variables. The results are reported in Table A.6, Columns 3 and 4, and lead to very similar conclusions.
} 
A birth is defined as the registration of a new company in the Registrar of Companies of the Ministry of Corporation ${ }^{5}$. Companies are assigned to the five groups reported in Table 1 based on the sector they operate in. Unfortunately, it is not always possible to assign a particular activity or project listed in the 2006 EIA notification to a specific sector. Projects/activities descriptions are sometimes too broad or too narrow to perfectly match a sector as defined in standard industrial classifications. It was, however, possible to recover some useful information from a previous draft of the EIA notification, which was circulated few months before the official approval of the reform, which provides a concordance table between sectors classification and activities using the National Industrial Classification (NIC). The concordance table was later removed from the official EIA notification. The list provided in the draft notification was supplemented by manually matching activities that did not report a corresponding sector code. The matching of sectors to activities was conducted at the 5-digit level and, when possible, sectors were aggregated at the highest level that allowed a one-to-one matching between activities and sectors. The entire list of sector-activity concordance used in the analysis is reported in Table A.1 of the Appendix while a summary is provided in Table 1. Some sub-sectors were dropped because of ambiguous matching with listed activities and are reported in Table A.3 of the appendix. Similar results are, however, obtained when these sectors are included and matched to the most plausible activity.

Table 3: Number of new firms by category and year of incorporation

\begin{tabular}{ccccccc}
\hline Year & Without EIA & Central-level & Capacity & ID & State-level & Total \\
\hline 1998 & 2346 & 160 & 1045 & 399 & 98 & 4048 \\
1999 & 2438 & 208 & 1273 & 483 & 131 & 4533 \\
2000 & 1780 & 154 & 1038 & 422 & 85 & 3479 \\
2001 & 1497 & 115 & 1128 & 343 & 95 & 3178 \\
2002 & 1747 & 154 & 1400 & 458 & 92 & 3851 \\
2003 & 2284 & 207 & 2200 & 590 & 111 & 5392 \\
2004 & 3133 & 225 & 3660 & 706 & 167 & 7891 \\
2005 & 4097 & 335 & 5799 & 952 & 200 & 11383 \\
2006 & 3966 & 351 & 6556 & 877 & 214 & 11964 \\
2007 & 4944 & 337 & 7084 & 1020 & 161 & 13546 \\
2008 & 4802 & 397 & 7984 & 833 & 155 & 14171 \\
2009 & 5058 & 350 & 4653 & 699 & 126 & 10886 \\
2010 & 6792 & 437 & 7297 & 980 & 187 & 15693 \\
2011 & 7405 & 477 & 7045 & 1226 & 193 & 16346 \\
2012 & 6534 & 404 & 5232 & 1007 & 117 & 13294 \\
Total & 58823 & 4311 & 63394 & 10995 & 2132 & 139655 \\
\hline Source & & & & & &
\end{tabular}

Source: author's calculations based on Orbis dataset.

The information contained in the Orbis database does not allow for the identification of a company's capacity or whether it was located within or outside an established industrial district. Therefore, it was not possible to distinguish whether a company belonging to groups 3 and 4 (defined as Capacity and ID) had undertaken the EIA at the central or state level. One attempt to distinguish large from small companies will, however, be made below using a measure of firm size. The number of births in each group and year is reported in Table 3. The same information is

\footnotetext{
${ }^{5}$ There is the possibility that a merger between two existing firms could be treated as a new entry if a new CIN is assigned. Nevertheless, I do not expect this to have a quantitatively relevant impact on the results given the limited number of firms with "amalgamated" status in the data (about 1\%). In addition, a change in the main activity during the period of analysis can also result in a new CIN been assigned to the company. Nevertheless, I do not expect this to have a significant influence on the results either, given that such a restructuring had to occur within a limited time span from the birth of a firm to affect the analysis, and so should not be frequently encountered in the data.
} 
reported by state and year in Table A.4 of the Appendix. I excluded the states and union territories of Andaman and Nicobar, Lakshadweep, Manipur, Mizoram, Nagaland, Tripura, Daman and Diu, Dadra and Nagar Haveli and Arunachal Pradesh because of insufficient firm level data and the lack of information on most enforcement measures. These states, however, represent only about $1 \%$ of the Indian population.

\subsection{Control variables}

Regressions include a set of control variables such as the number of new special economic zones (SEZs) in polluting sectors by sector-state and year, obtained from the Department of Commerce of the Ministry of Commerce and Industry, electricity prices, and changes in minimum wages in polluting sectors, which are both provided by IndiaStat. They also include average wages by year and state that are provided by the Ministry of Statistics and Programme Implementation (Government of India, 2012) and are calculated from the Annual Survey of Industries that collects information on medium and large firms in India. Wages are deflated using state-level price indexes (source: IndiaStat).

\section{$5 \quad$ Firm births and environmental enforcement}

This section begins with some motivating evidence based on the relationship between state-level enforcement and firm births across treated and untreated sectors.

Figure 1 plots the raw data and compares trends in births of polluting firms by level of enforcement and treatment groups. The underlying trends in births by group are depicted in Figure 3 of the Appendix. The graphs report 3-year moving averages of the number of new firms, since annual values were too noisy in particular for the State group. States are classified into low and high enforcing states (bottom and top 6 states respectively) and the data are normalized by 2006 values. All panels show fairly similar trends in the pre-reform period between high and low enforcing states. On the other hand, for sectors affected by decentralization (panel b c and d), the patterns diverge after the implementation of the reform. In particular, while firm births in low enforcing states followed pre-reform trends, it is possible to observe a slowdown in births in high enforcing states. These compelling patterns in the data suggest that decentralization was associated with relatively fewer firm births in states with stricter environmental enforcement. Before turning to the regression analysis in the next section, Figure 2 provides a more formal visual assessment of the effects of the reform. It also offers the opportunity to test the assumption of common trends underlying the estimations that follow. The graphs are derived from regressing the number of firm births on a full set of state-by-sector fixed effects and a triple interaction term between the enforcement index, group dummies and year fixed effects. Each panel plots the resulting time-varying coefficients and the respective 95 percent confidence interval. They show the impact of environmental enforcement on firm births over time for each group, as indicated in the title of each graph. The comparison group is the No-EIA group that comprises non-polluting sectors.

Figure 2 shows evidence that the reform has altered the relationship between firm births and state-level environmental enforcement in sectors under the competence of state-level authorities (panel d). For these treated sectors, higher enforcement at the state-level led to a decrease in firm births after the implementation of the reform. It is also possible to notice a sharp decline for the Industrial District group (panel c), although the effect does not persist. There is no evidence of impact, instead, for the Capacity group. Nevertheless, these two latter groups include a mix of treated and untreated firms so the absence of a significant impact overall might still hide some 
Figure 1: Number of new polluting firms by groups and enforcement level

(a) Central (untreated)

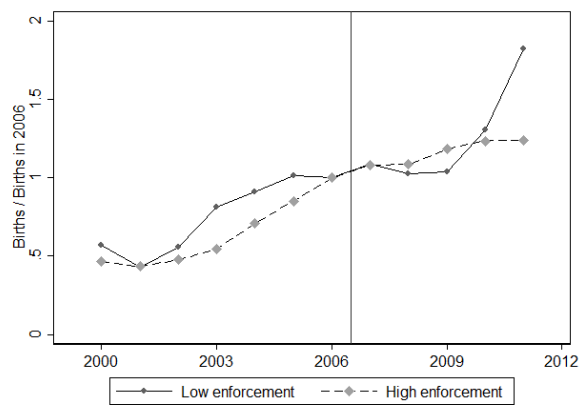

(c) ID (mixed treated/untreated)

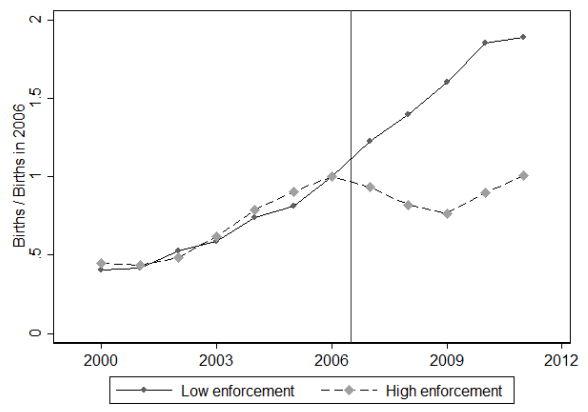

(b) Capacity (mixed treated/untreated)

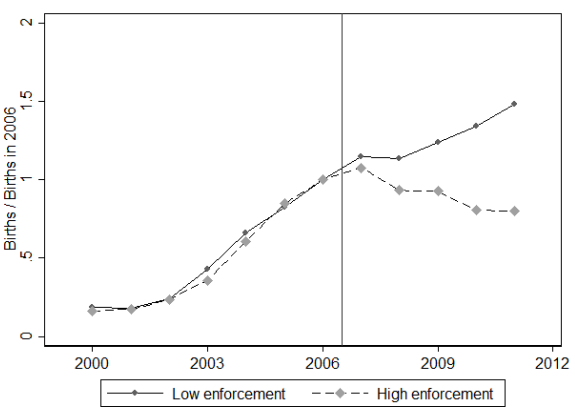

(d) State (treated)

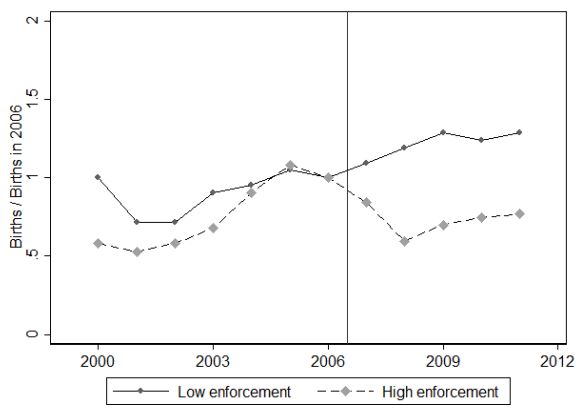

Author's calculation based on the Orbis database. The plots are based on 3-year moving averages. The number of new firms is divided by 2006 values so that a value of 1.3 indicates an increase in firm births of $30 \%$ with respect to 2006 .

effects that I will try to partly capture in the next section by using firm size as a proxy for capacity.

The empirical analysis that follows focuses on the impact of decentralization for which the above graphs serve as a test of the parallel trends hypothesis. Both panels support the validity of the empirical design showing no evidence of differential effects of enforcement across groups before 2006. The identification of the effect of public consultations, which affected all polluting activities, would require stronger assumptions, i.e. parallel trends across groups rather than across groups and enforcement levels, that are not fully met by all groups, hence the focus on decentralization only.

\section{Empirical model}

This section presents the empirical framework used to estimate the impact of the 2006 EIA reform on the birth of polluting firms. It adopts a triple differences approach where the control group includes non-polluting sectors (group 1), and the treated sectors are those included in groups 3, 4 and 5. An additional group of untreated polluting firms is also included separately (group 2). While environmental clearance is required for both new firms and the expansion or modernization of existing polluting firms, the empirical analysis considers only the creation of

new firms. While high start-up costs due to environmental clearance have a direct negative effect 
Figure 2: Event study: the effect of the EIA reform on firm births

$\begin{array}{ll}\text { (a) Central (untreated) } & \text { (b) Capacity (mixed treated/untreated) }\end{array}$

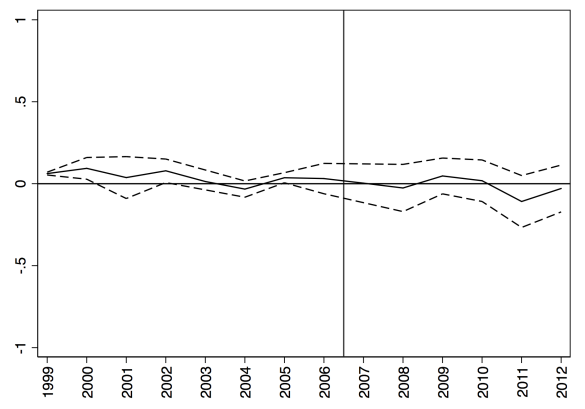

(c) ID (mixed treated/untreated)

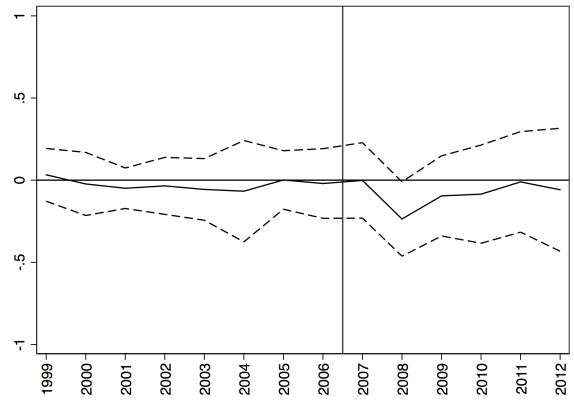

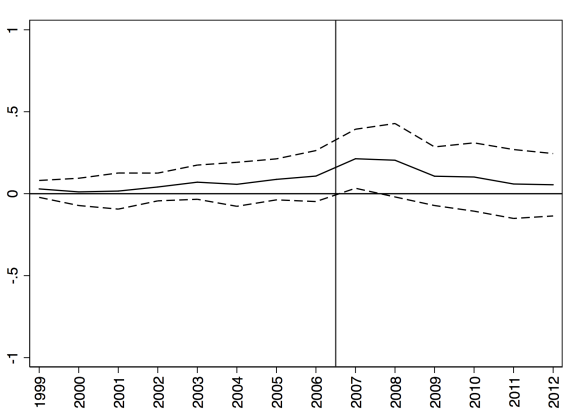

(d) State (treated)

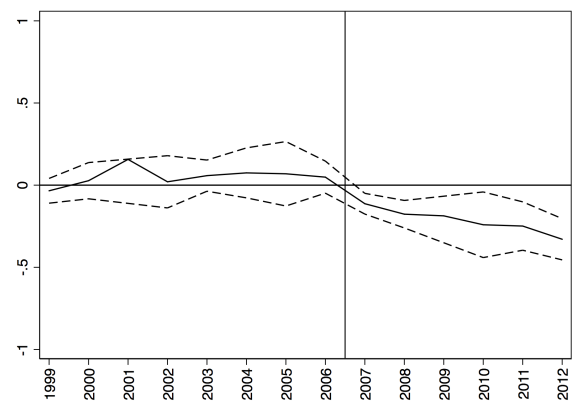

Author's calculation based on the Orbis database. The plots are created by regressing the log of new firms by sectorstate on a full set of event time indicators interacted with the state-level enforcement index and group dummies controlling for state-by-year fixed effects. The comparison group is the No-EIA group. The dashed line indicates $95 \%$ confidence interval. 
on entry, firm exit can also be affected but only indirectly through less competition or low incentives to grow. Hence, this paper focuses only on firm entry as further discussed below. The baseline regression is the following:

$$
\begin{array}{r}
n_{i j t}=\beta_{1}\left(D_{t} \times E_{j}\right)+\beta_{2}\left(D_{t} \times E_{j} \times \boldsymbol{G}_{i}\right)+\alpha^{\prime} \mathbf{x}_{i j t} \\
+\rho_{0}^{\prime} \mathbf{w}_{t}+\rho_{1}^{\prime}\left(\mathbf{w}_{t} \times \boldsymbol{G}_{i}\right)+\gamma^{\prime} \mathbf{d}_{i j}+\epsilon_{i j t},
\end{array}
$$

where $n_{i j t}$ is the number of new firms in sector $i$, state $j$ and year $t, \mathbf{x}_{i j t}$ is a vector of control variables, $\mathbf{d}_{i j}$ is a set of state-sector fixed effects and $\mathbf{w}_{t}$ are time fixed effects. $D_{t}$ is a dummy variable taking value one for the years following the implementation of the EIA notification. The treatment effect is allowed to be heterogeneous depending on the level of enforcement in each state, $E_{j}$. Finally, $\boldsymbol{G}_{i}$ is a vector of binary variables indicating the treatment group as reported in Table 1. The excluded group is composed by non-polluting sectors that do not undertake the EIA (group 1: No EIA). I expect the coefficient of the triple interaction term, $\beta_{2}$, to differ between sectors treated by decentralization (group 5: State) and untreated sectors (group 2: Central). In particular, I expect environmental enforcement at the state level to have a larger negative effect on the birth of polluting firms in treated sectors. For groups 3 (Capacity) and 4 (ID) the effect is expected to be smaller as they contain a mixture of treated and untreated firms.

This approach, de facto, compares the average number of new firms born before and after the implementation of the EIA reform, conditioned on the level of enforcement in each state. Whether firms tended to prefer low enforcing states also prior to the reform, because of low supervision and monitoring costs, does not affect the results as long as this behavior was uniform across groups. A formal test is provided in the next section.

The expected effect of this decentralization process is twofold. Some states might impose more stringent conditions than those imposed previously by the central government resulting in a reduction of births in high enforcing states (deterrence). On the other hand, some states might conduct a less strict EIA in order to promote industrialization, or due to technical and financial constraints, facilitating the birth of new polluting firms (attraction). Both forces lead to relative lower birth rates in higher-enforcing states compared to lower-enforcing states. Because the relevance of the initial start-up costs varies across sectors, depending on the type and size of the pollution control measures required, the effect of the reform is likely to be more visible in sectors where the influence of such fixed costs is higher. Unfortunately, it is not possible to identify which sectors are likely to incur greater costs, under enforcement, given the lack of systematic information on the types and costs of pollution control requirements by sector. Therefore, the model assumes homogeneous effects across sectors. Moreover, to reduce the scope for reverse causality due to enforcement capacity being affected by the number of firms applying for environmental clearance, for example because of technical constraints or increased public awareness, the level of enforcement across states is fixed to pre-reform levels.

The model is estimated both using a simple semi-log linear estimator (OLS) and a Poisson pseudo-maximum-likelihood estimator with robust standard errors (Wooldridge, 1991). The latter allows for the discreteness of the dependent variable and the large number of zeros. The estimator produces consistent estimates under relatively weaker assumptions than a standard Poisson model, but has difficulties to converge when a large number of fixed effects are included.

Because the model includes state-sector and year fixed effects it is not possible to identify the effects of pure location, time and sector-specific variables. All specifications will control for the average share of new firms by state ${ }^{6}$ since the level of enforcement could be correlated with other

\footnotetext{
${ }^{6}$ This is a state-level measure computed by averaging the shares of firms born in a given state and sector over the total number of births in the sector. The simple average ensures that the state-level measure is neutral to the importance of a particular sector in a given state.
} 
institutional characteristics leading to states experiencing differential growth rates, and the total number of new firms in a sector. These linear controls, however, are also substituted by sector-year and state-year fixed effects. Additional controls will be discussed in the next sections. Although the EIA reform was introduced in September 2006, the decentralization process could not actually take place unless a SEIAA was created. Because most of the SEIAAs were established between 2007 and 2008 (table A.2 in the appendix), the variable $D_{t}$ will take value one for the post-2007 period. Using a common treatment year for all states helps avoiding endogeneity issues, for example due to poorer states having lower enforcement levels and delaying the creation of the SEIAA. Moreover, the creation of a SEIAA can have spillover effects in states where the authority has not yet been established due to cross-border relocations of firms. Nevertheless, results are also shown using the actual year of establishment of the SEIAA (Table A.5 of the Appendix).

\subsection{Identification issues}

At the aggregate level, enforcement capacity can be both the cause and the consequence of firms' location choices. A larger number of polluting firms may increase the awareness of the public and the media about pollution and lead to increasing pressure to control pollution. On the other hand, however, more polluting firms may put pressure on the capacity of state-level authorities to deal with non-compliance and reduce the ability of the authorities to monitor and punish polluters. By considering only the number of new firms created each year in each state and sector this problem is substantially reduced. Moreover, the measures of enforcement considered in the regressions are time-invariant and, therefore, do not lead to a spurious correlation between changes in enforcement over time and changes in the number of new firms. They also refer to the pre-reform period and are, therefore, not influenced by the reform. Although all specifications control for the presence of state, location and year-level unobservables, unobserved heterogeneity could still be a concern. Nevertheless, the regressor of central interest is a three-way interaction term, between state-level enforcement, a dummy variable indicating the post-implementation period and a group dummy, and is less subject to endogeneity problems. Moreover, the results are tested for robustness to the inclusion of additional control variables that should capture other sources of unobserved variation over time, such as changes in minimum and average real wages, electricity prices, the number of special economic zones, and sector and state by year fixed effects. In cross-sectional studies of environmental regulation it is often argued that failing to control for corruption creates a problem of omitted variable bias (Dean et al., 2009). High corruption often implies lower environmental stringency but may also act as a deterrent for new investments. This is not a concern in this study. Corruption is included as a measure of environmental stringency since it is the best available measure of the quality of state-level institutions and it is likely that its effect as deterrent for new businesses should not vary before and after the implementation of the EIA notification between treatment groups.

\section{Empirical results}

This section begins presenting the results of estimating Equation 1 using the simplest linear model. The results are reported in Table 4. Columns 2 to 6 show the effects of each of the five individual enforcement measures included in the environmental enforcement index used in Column 1. All specifications include state-by-sector and year fixed effects. The dependent variable is the log of new firms in each sector-state cell. A set of group dummies indicates whether the sectors are non-polluting (No EIA, the omitted baseline) or subject to different EIA criteria (Central, Capacity, ID and State). These dummies are interacted with the post-reform 
dummy $\left(D_{t}\right)$ and the enforcement index at the state level $\left(E_{j}\right)$ to estimate how firm births have been affected by the reform depending on the enforcement capacity of states. Standard errors are clustered at the state level. Moreover, to further deal with potential serial correlation at the treatment level, I follow Bertrand et al. (2004) and obtain similar results using bootstrapped standard errors and averages of pre- and post-reform data (Table A.7 of the Appendix).

Table 4: Base results: log-linear model. Impact of the EIA reform by groups

\begin{tabular}{|c|c|c|c|c|c|c|}
\hline \multicolumn{7}{|c|}{ Dependent variable: log of new firms by sector } \\
\hline & (1) & (2) & (3) & (4) & $(5)$ & (6) \\
\hline & Index & NGOs & Judgments & Corruption & News & Monitor \\
\hline$D_{t} \times$ Central (A) & $\begin{array}{c}-0.162^{* *} \\
(0.060)\end{array}$ & $\begin{array}{c}-0.102 \\
(0.078)\end{array}$ & $\begin{array}{c}-0.148^{* * *} \\
(0.042)\end{array}$ & $\begin{array}{c}-0.139^{* *} \\
(0.049)\end{array}$ & $\begin{array}{c}-0.125^{*} \\
(0.062)\end{array}$ & $\begin{array}{c}-0.139^{* *} \\
(0.057)\end{array}$ \\
\hline$D_{t} \mathrm{x}$ Capacity $(\mathrm{A} / \mathrm{B})$ & $\begin{array}{l}-0.080 \\
(0.061)\end{array}$ & $\begin{array}{l}-0.099 \\
(0.058)\end{array}$ & $\begin{array}{l}-0.088^{*} \\
(0.051)\end{array}$ & $\begin{array}{l}-0.092^{*} \\
(0.052)\end{array}$ & $\begin{array}{l}-0.093^{*} \\
(0.054)\end{array}$ & $\begin{array}{c}-0.125^{* *} \\
(0.050)\end{array}$ \\
\hline$D_{t} \times \mathrm{ID}(\mathrm{A} / \mathrm{B})$ & $\begin{array}{c}0.095 \\
(0.067)\end{array}$ & $\begin{array}{c}0.135 \\
(0.089)\end{array}$ & $\begin{array}{l}0.112^{*} \\
(0.055)\end{array}$ & $\begin{array}{c}0.042 \\
(0.062)\end{array}$ & $\begin{array}{c}0.144^{* *} \\
(0.065)\end{array}$ & $\begin{array}{c}0.063 \\
(0.072)\end{array}$ \\
\hline$D_{t} \times$ State $(\mathrm{B})$ & $\begin{array}{c}0.078 \\
(0.055)\end{array}$ & $\begin{array}{c}0.123 \\
(0.089)\end{array}$ & $\begin{array}{c}0.054 \\
(0.065)\end{array}$ & $\begin{array}{l}-0.101 \\
(0.077)\end{array}$ & $\begin{array}{c}0.016 \\
(0.067)\end{array}$ & $\begin{array}{l}-0.025 \\
(0.083)\end{array}$ \\
\hline$D_{t} \times E_{j}$ & $\begin{array}{c}0.019 \\
(0.035)\end{array}$ & $\begin{array}{l}0.010^{* *} \\
(0.004)\end{array}$ & $\begin{array}{c}0.043 \\
(0.028)\end{array}$ & $\begin{array}{l}0.012^{*} \\
(0.006)\end{array}$ & $\begin{array}{c}0.001^{* *} \\
(0.000)\end{array}$ & $\begin{array}{l}-0.001 \\
(0.004)\end{array}$ \\
\hline$D_{t} \times E_{j} \times$ Central $(\mathrm{A})$ & $\begin{array}{c}0.045 \\
(0.032)\end{array}$ & $\begin{array}{l}-0.002 \\
(0.006)\end{array}$ & $\begin{array}{c}0.033 \\
(0.033)\end{array}$ & $\begin{array}{l}-0.019 \\
(0.012)\end{array}$ & $\begin{array}{c}0.000 \\
(0.000)\end{array}$ & $\begin{array}{c}0.004 \\
(0.005)\end{array}$ \\
\hline$D_{t} \times E_{j} \times$ Capacity $(\mathrm{A} / \mathrm{B})$ & $\begin{array}{c}0.020 \\
(0.027)\end{array}$ & $\begin{array}{c}0.006 \\
(0.004)\end{array}$ & $\begin{array}{l}-0.001 \\
(0.025)\end{array}$ & $\begin{array}{l}-0.013 \\
(0.008)\end{array}$ & $\begin{array}{c}0.000 \\
(0.000)\end{array}$ & $\begin{array}{c}0.008 \\
(0.005)\end{array}$ \\
\hline$D_{t} \times E_{j} \times \mathrm{ID}(\mathrm{A} / \mathrm{B})$ & $\begin{array}{c}-0.068^{*} \\
(0.039)\end{array}$ & $\begin{array}{c}-0.013^{*} \\
(0.007)\end{array}$ & $\begin{array}{c}-0.078^{*} \\
(0.038)\end{array}$ & $\begin{array}{c}0.010 \\
(0.012)\end{array}$ & $\begin{array}{c}-0.001^{* * *} \\
(0.000)\end{array}$ & $\begin{array}{l}-0.002 \\
(0.005)\end{array}$ \\
\hline$D_{t} \times E_{j} \times$ State $(\mathrm{B})$ & $\begin{array}{c}-0.152^{* *} \\
(0.055)\end{array}$ & $\begin{array}{c}-0.028^{* * *} \\
(0.007)\end{array}$ & $\begin{array}{c}-0.152^{* * *} \\
(0.043)\end{array}$ & $\begin{array}{c}0.002 \\
(0.017)\end{array}$ & $\begin{array}{c}-0.001^{* *} \\
(0.000)\end{array}$ & $\begin{array}{r}-0.009^{*} \\
(0.005)\end{array}$ \\
\hline State-Sector FE & Yes & Yes & Yes & Yes & Yes & Yes \\
\hline Year FE & Yes & Yes & Yes & Yes & Yes & Yes \\
\hline Observations & 11709 & 12749 & 12749 & 11709 & 12749 & 12749 \\
\hline State-sectors & 1411 & 1676 & 1676 & 1411 & 1676 & 1676 \\
\hline $\mathrm{P}$-value of t-test for coeffici & ats of tripl & interaction & & & & \\
\hline Central = Capacity & 0.284 & 0.238 & 0.347 & 0.579 & 0.411 & 0.435 \\
\hline Central $=\mathrm{ID}$ & 0.006 & 0.303 & 0.026 & 0.077 & 0.001 & 0.289 \\
\hline Central $=$ State & 0.005 & 0.013 & 0.000 & 0.283 & 0.005 & 0.081 \\
\hline
\end{tabular}

Standard errors clustered at the state level in parentheses. ${ }^{*} p<0.1,{ }^{* *} p<0.05,{ }^{* * *} p<0.01$. This table reports only the relevant interaction terms. All specifications are, however, estimated including all interaction terms as reported in Equation 1. They also include the average share of new firms in each state-year and the total number of new firms in each sector-year, which have been omitted from the table. $D_{t}$ is a dummy indicating the post-reform period and $E_{j}$ is enforcement at state-level. These are interacted with category dummies: Central, Capacity, ID and State. The omitted category is "No EIA" (non-polluting firms). The enforcement measure used in each specification is indicated in the column header. Individual measures of enforcement are standardized to have mean zero.

Results show that the decentralization of the EIA process has led to a relative decrease in firm births in states with higher environmental enforcement for treated sectors. Considering Column 1, the strength of environmental enforcement is shown to have a larger negative effect, after the reform, for firms in sectors of exclusive competence of SEIAA authorities (State, category B). The coefficient of the triple interaction term for the State group is negative and statistically different from that of the untreated group (Central), as shown by the t-tests reported at the bottom of the table. The overall effect of the reform for the State group can be computed considering the 
coefficient of the interaction term " $D_{t} \times$ State (B)" (not significant) and of the triple interaction term " $D_{t} \times E_{j} \times$ State (B)" 7 . The insignificant coefficient of the " $D_{t} \times$ State (B)" term suggests that for a state of average enforcement capacity, decentralization did not strengthen pollution $\operatorname{control}^{8}$. However, because the enforcement index ranges between -2.22 and 3.13, results indicate that the reform led to an increase in births in low enforcing states and a decrease in births in high-enforcing states with respect to the baseline. The effect is economically relevant. A one-standard deviation (1.6) increase in the enforcement index produces a $17 \%$ decrease in the number of new firms. A similar effect is also found for firms subject to state-level EIA if located within an industrial district while the coefficient related to the third group of sectors (Capacity) is very small and not statistically significant. This latter group comprises a mix of treated and untreated firms that are subject to state-level EIA only if of small capacity. The results seem to suggest that most companies are of large capacity and, therefore, unaffected by the reform. This issue will be explored further below. The results are consistent across all different individual measures of enforcement, although, in few instances, some coefficients are not significant ${ }^{9}$. Table 5 tests the robustness of the results to the inclusion of additional control variables. The first column control for the number of new special economic zones (SEZs) in polluting sectors by sector-state and year. SEZs offer notable advantages, such as tax exemptions, to new firms. India is one the first countries to recognize the importance of SEZs and the first zone was created in 1965. The Indian government passed the SEZ act in 2005 in order to increase investors' confidence. The bill was implemented in 2006 and brought about a simplification of the bureaucratic procedures. While most of the SEZs involve only the information technology sectors (55\%) it is still important to consider those that concerned polluting sectors (about $20 \%$ including general multi-product SEZs) as they could induce possible confounding effects if omitted. The creation of a SEZ has a positive impact on the number of new firms while the results pertaining the reform remain almost unchanged.

Results reported in Columns 2 and 3 of Table 5 are obtained after controlling for the average wage in each state and year, and changes in minimum wages in polluting sectors. The inclusion of these variables does not significantly affect the results. Changes in average wages do not have a significant effect on firm births. While wages are usually found to be an important determinant of firms' location decisions, their poor performance in these specifications could be attributed to the limited variation in real wages over time.

The specification reported in Column 4 controls for changes in electricity prices that could affect location choices and be also potentially correlated with environmental enforcement. Differences in electricity prices, however, are likely to weakly reflect the commitment towards the environment of Indian states. Energy prices are instead a powerful political tool. Higher prices for the commercial and industrial sectors are often imposed to subsidize the agricultural sector and the rural poor, in particular in the proximity of state elections (Badiani et al., 2012). The results are

\footnotetext{
${ }^{7}$ The overall effects depends on the level of enforcement according to the following relationship: $\frac{\delta n_{i j t}}{\delta D_{t}}=0.078-$ $0.152 \times E_{j}$.

${ }^{8}$ The negative and significant coefficient of " $D_{t} \times$ Central $(\mathrm{A})$ ", combined with the insignificant interaction term, would suggest that sectors in the Central group experienced a generalized decline in firm births in the post reform period across all states independently of the level of enforcement. This effect could be picking up the impact of the first component of the reform, i.e. a greater emphasis on public consultation that affected all polluting activities (both A and B projects), including those under the competence of the central authorities. This coefficient, however, is not stable. It changes sign or becomes insignificant in following specifications (Poisson estimates). Moreover, this interpretation requires stronger identification assumptions as described in section 5. I, therefore, prefer to treat this result with caution.

${ }^{9}$ Similar results are obtained for all enforcement measures when excluding the Union territories for which corruption data are not available.
} 
Table 5: Log-linear model: additional control variables

\begin{tabular}{|c|c|c|c|c|c|c|c|}
\hline \multicolumn{8}{|c|}{ Dependent variable: log of new firms by sector } \\
\hline & (1) & $(2)$ & $(3)$ & $(4)$ & $(5)$ & (6) & $(7)^{a}$ \\
\hline$D_{t} \mathrm{x}$ Central $(\mathrm{A})$ & $\begin{array}{c}-0.158^{* *} \\
(0.059)\end{array}$ & $\begin{array}{c}-0.159 * * \\
(0.059)\end{array}$ & $\begin{array}{c}-0.164^{* *} \\
(0.059)\end{array}$ & $\begin{array}{c}-0.163^{* *} \\
(0.058)\end{array}$ & $\begin{array}{c}-0.144^{* *} \\
(0.062)\end{array}$ & $\begin{array}{c}0.835^{* * *} \\
(0.229)\end{array}$ & $\begin{array}{c}0.674^{* *} \\
(0.285)\end{array}$ \\
\hline$D_{t} \mathrm{x}$ Capacity $(\mathrm{A} / \mathrm{B})$ & $\begin{array}{l}-0.073 \\
(0.060)\end{array}$ & $\begin{array}{l}-0.073 \\
(0.058)\end{array}$ & $\begin{array}{l}-0.087 \\
(0.060)\end{array}$ & $\begin{array}{l}-0.085 \\
(0.061)\end{array}$ & $\begin{array}{l}-0.034 \\
(0.056)\end{array}$ & $\begin{array}{c}2.201^{* * *} \\
(0.437)\end{array}$ & $\begin{array}{c}2.189^{* * *} * \\
(0.452)\end{array}$ \\
\hline$D_{t} \times \operatorname{ID}(\mathrm{A} / \mathrm{B})$ & $\begin{array}{c}0.094 \\
(0.067)\end{array}$ & $\begin{array}{c}0.094 \\
(0.067)\end{array}$ & $\begin{array}{l}0.074 \\
(0.076)\end{array}$ & $\begin{array}{c}0.078 \\
(0.077)\end{array}$ & $\begin{array}{c}0.109 \\
(0.067)\end{array}$ & $\begin{array}{c}0.944^{* *} \\
(0.342)\end{array}$ & $\begin{array}{l}1.242^{* *} \\
(0.462)\end{array}$ \\
\hline$D_{t} \times$ State $(\mathrm{B})$ & $\begin{array}{l}0.083 \\
(0.056)\end{array}$ & $\begin{array}{c}0.082 \\
(0.056)\end{array}$ & $\begin{array}{l}0.080 \\
(0.056)\end{array}$ & $\begin{array}{l}0.076 \\
(0.055)\end{array}$ & $\begin{array}{l}-0.035 \\
(0.065)\end{array}$ & $\begin{array}{l}1.289^{*} \\
(0.638)\end{array}$ & $\begin{array}{l}1.671^{* *} \\
(0.640)\end{array}$ \\
\hline$D_{t} \times E_{j}$ & $\begin{array}{l}0.006 \\
(0.035)\end{array}$ & $\begin{array}{l}0.006 \\
(0.035)\end{array}$ & $\begin{array}{l}0.006 \\
(0.035)\end{array}$ & $\begin{array}{l}0.016 \\
(0.037)\end{array}$ & $\begin{array}{c}0.106^{* * *} \\
(0.013)\end{array}$ & $\begin{array}{c}0.168^{* * * *} \\
(0.021)\end{array}$ & $\begin{array}{c}0.046^{* * *} \\
(0.008)\end{array}$ \\
\hline$D_{t} \times E_{j} \times$ Central $(\mathrm{A})$ & $\begin{array}{l}0.049 \\
(0.032)\end{array}$ & $\begin{array}{c}0.049 \\
(0.032)\end{array}$ & $\begin{array}{c}0.050 \\
(0.032)\end{array}$ & $\begin{array}{l}0.050 \\
(0.032)\end{array}$ & $\begin{array}{c}0.043 \\
(0.034)\end{array}$ & $\begin{array}{c}0.030 \\
(0.032)\end{array}$ & $\begin{array}{c}0.014 \\
(0.010)\end{array}$ \\
\hline$D_{t} \mathrm{x} E_{j} \mathrm{x}$ Capacity $(\mathrm{A} / \mathrm{B})$ & $\begin{array}{c}0.023 \\
(0.027)\end{array}$ & $\begin{array}{c}0.022 \\
(0.027)\end{array}$ & $\begin{array}{c}0.021 \\
(0.027)\end{array}$ & $\begin{array}{c}0.020 \\
(0.027)\end{array}$ & $\begin{array}{l}-0.007 \\
(0.026)\end{array}$ & $\begin{array}{l}-0.010 \\
(0.033)\end{array}$ & $\begin{array}{l}-0.001 \\
(0.009)\end{array}$ \\
\hline$D_{t} \times E_{j} \times \mathrm{ID}(\mathrm{A} / \mathrm{B})$ & $\begin{array}{r}-0.072^{*} \\
(0.039)\end{array}$ & $\begin{array}{r}-0.072^{*} \\
(0.039)\end{array}$ & $\begin{array}{r}-0.074^{*} \\
(0.040)\end{array}$ & $\begin{array}{r}-0.077^{*} \\
(0.040)\end{array}$ & $\begin{array}{l}-0.077^{*} \\
(0.044)\end{array}$ & $\begin{array}{c}-0.098^{* *} \\
(0.044)\end{array}$ & $\begin{array}{r}-0.028^{*} \\
(0.015)\end{array}$ \\
\hline$D_{t} \times E_{j} \times$ State $(\mathrm{B})$ & $\begin{array}{c}-0.149^{* *} \\
(0.056)\end{array}$ & $\begin{array}{c}-0.149^{* *} \\
(0.056)\end{array}$ & $\begin{array}{c}-0.150^{* *} \\
(0.056)\end{array}$ & $\begin{array}{c}-0.149^{* *} \\
(0.056)\end{array}$ & $\begin{array}{l}-0.100^{*} \\
(0.050)\end{array}$ & $\begin{array}{c}-0.128^{* *} \\
(0.052)\end{array}$ & $\begin{array}{c}-0.036^{* *} \\
(0.015)\end{array}$ \\
\hline SEZ & $\begin{array}{l}0.036^{*} \\
(0.020)\end{array}$ & $\begin{array}{l}0.035^{*} \\
(0.019)\end{array}$ & $\begin{array}{l}0.035^{*} \\
(0.019)\end{array}$ & $\begin{array}{l}0.034^{*} \\
(0.018)\end{array}$ & & & \\
\hline Average wages & & $\begin{array}{l}18.566 \\
(67.354)\end{array}$ & $\begin{array}{c}23.737 \\
(67.076)\end{array}$ & $\begin{array}{c}-0.046 \\
(74.909)\end{array}$ & & & \\
\hline Minimum wage & & & $\begin{array}{l}0.001 \\
(0.000)\end{array}$ & $\begin{array}{c}0.001 \\
(0.000)\end{array}$ & & & \\
\hline Electricity price & & & & $\begin{array}{l}-0.399^{*} \\
(0.219)\end{array}$ & & & \\
\hline State-Sector FE & Yes & Yes & Yes & Yes & Yes & Yes & Yes \\
\hline Year FE & Yes & Ye & $\mathrm{Ye}$ & $\mathrm{Ye}$ & $\mathrm{Ye}$ & $\mathrm{Ye}$ & Yes \\
\hline State-year FE & No & No & No & No & Yes & $\mathrm{Ye}$ & Yes \\
\hline Sector-year FE & No & No & No & No & No & Yes & Yes \\
\hline Observations & 11709 & 11709 & 11709 & 11709 & 11709 & 11709 & 11709 \\
\hline & 1411 & 1411 & 1411 & 1411 & 1411 & 1411 & 1411 \\
\hline $\mathrm{P}$-value of t-test & nts of trip & interactio & & & & & \\
\hline $1=$ Capacity & 0.267 & 0.247 & 0.203 & 0.185 & 0.071 & 0.130 & 0.079 \\
\hline$=\mathrm{ID}$ & 0.003 & 0.003 & 0.003 & 0.003 & 0.006 & & 0.002 \\
\hline Central $=$ State & 0.005 & 0.005 & 0.005 & 0.004 & 0.014 & 0.008 & 0.002 \\
\hline
\end{tabular}

Standard errors clustered at the state level in parentheses. ${ }^{*} p<0.1,{ }^{* *} p<0.05,{ }^{* * *} p<0.01$. This table reports only the relevant interactions terms. All specifications are, however, estimated including all interaction terms as reported in Equation 1. $D_{t}$ is a dummy indicating the post-reform period and $E_{j}$ is the enforcement index at state-level. These are interacted with category dummies: Central, Capacity, ID and State. The omitted category is "No EIA" (non-polluting firms). ${ }^{a}$ In Column 7 the enforcement index indicates the rank of a state where 1 indicates the state with the lowest level of enforcement and 20 the state with the highest level of the ranking.

robust to the inclusion of electricity prices that are found to have a negative effect on firm births. The results obtained so far have helped to deal with the concern that variations in environmental enforcement across states could proxy for differences in other state level unobservable characteristics. It is, however, possible that some differences in the policy environment remain unmeasured. The results reported in Columns 5 and 6 substitute linear controls with state-by-year and sector-by-year fixed effects and show similar effects. Finally, the last column uses the ranking of states by level of enforcement rather than the actual values of the index. Results show that moving up one position in the ranking decreases the number of firm births by $3.6 \%$ on average. 


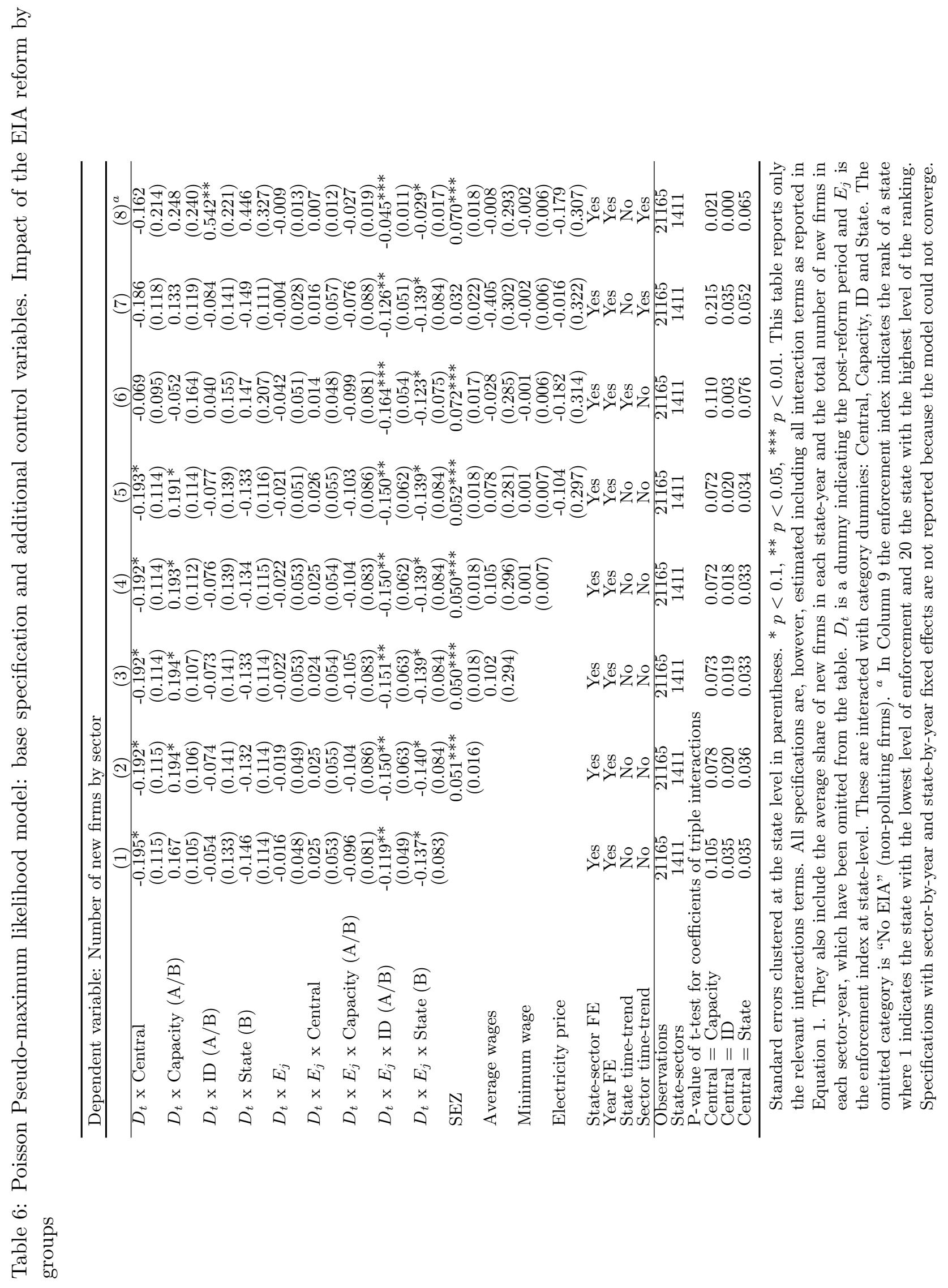


Table 6 reports the results obtained using the Poisson pseudo-maximum-likelihood estimator. These results also support the central hypothesis: decentralization has produced a relative decrease in firm births in states with greater enforcement capacity. The results are robust to the inclusion of the additional control variables, previously described, as reported in Columns 2 to 6 . An additional robustness check involves a placebo difference in difference exercise considering firm births in pre-treatment period. Table A.8 of the Appendix reports the estimates of three specifications that consider 2003, 2004 and 2005 as fake treatment events. The estimates of the interaction terms from the placebo tests are not statistically different from zero in all specifications.

\subsection{Small versus large capacity firms}

Table 7: Small versus large companies in the "Capacity" group

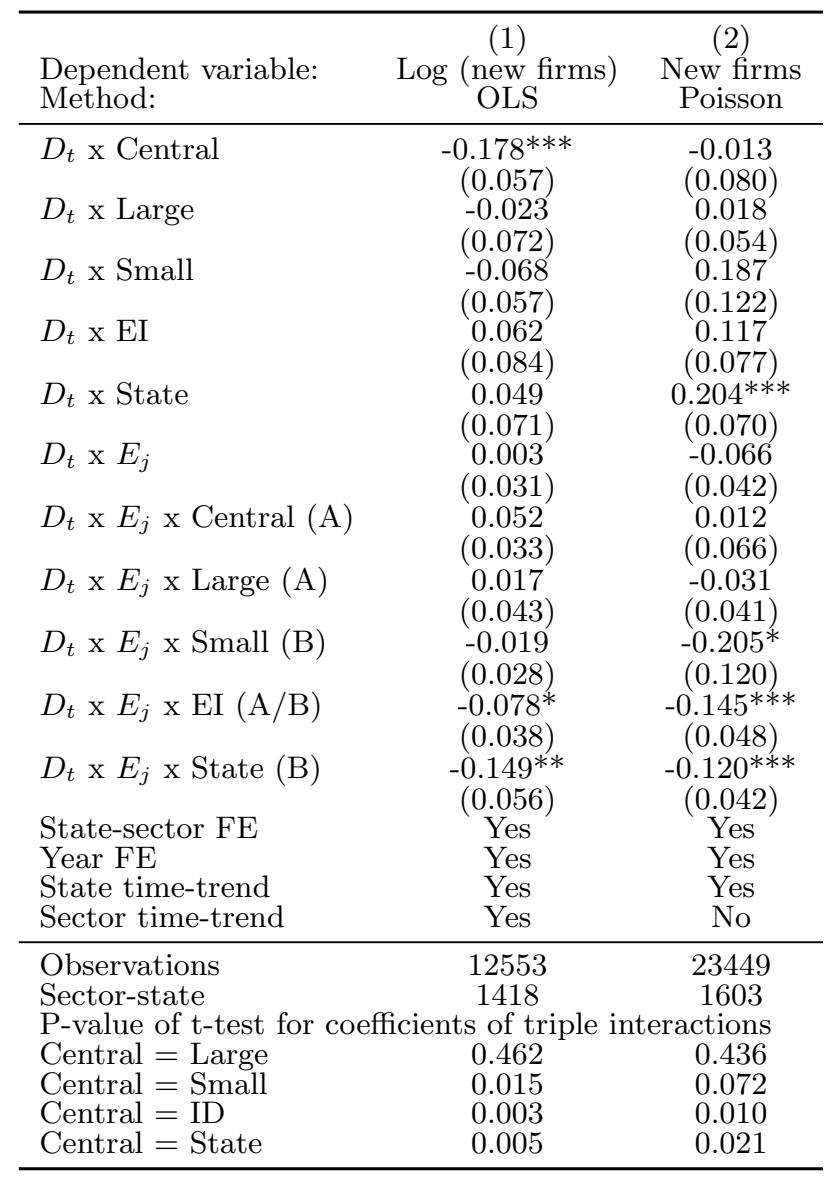

Standard errors are clustered at the state level. * $p<0.1,{ }^{* *} p<0.05$, *** $p<0.01$. This table reports only the relevant interactions terms. $D_{t}$ is a dummy indicating the post-reform period and $E_{j}$ is the enforcement index at state-level. These are interacted with category dummies: Central, Capacity, ID and State. The omitted category is "No EIA" (nonpolluting firms).

The Capacity group includes a mix of treated and untreated firms since new firms are subject to 
state-level EIA based on capacity, which is not observed in the data. In this section, I use firm size as a proxy for capacity in an attempt to separate treated from untreated firms. In particular, I consider the classification of companies constructed by Bureau van Dijk, the commercial provider of the Orbis database (Kalemli-Ozcan et al., 2015). This classification allows the distinction between small, medium and large firms and is based on a mix of information on annual turnover, operating revenues or employees ${ }^{10}$. Although this classification is not intended to measure capacity it can provide a reasonable approximation. The results reported in Table 7 show that the effect is indeed negative and much larger for small firms, i.e. those more likely to be subject to state-level EIA. The effect is more evident considering the Poisson pseudo-maximum-likelihood estimation. This confirms once again that the observed negative effects can be attributed to the decentralization process that has affected only certain polluting activities such as small firms in selected sectors (listed in Table 1 under Capacity group).

\section{Discussion and policy implications}

The results obtained so far point towards a negative effect of state-level environmental enforcement on firm births after decentralization. This conclusion is reinforced when considering the possibility that states applying a more stringent environmental clearance process may attempt to mitigate its negative effects by offering financial incentives to new plants. Overall, the decrease in the number of polluting firms in high-enforcing states has been substantially larger than the increase experienced by low enforcing states given the smaller size of their economies. A simple back-of-the-envelope estimation of the overall impact of decentralization can be obtained by predicting state-level changes in firm births using the coefficients of the interactions terms multiplied by the enforcement index. The impact is economically relevant. About 1200 new firms where established in sectors belonging to the State group across all India in the pre-reform period (from 1998 to 2006) versus 930 in the post-reform period. The estimate indicates that as many as $250(20 \%)$ additional new firms would have been created in the absence of decentralization over the entire post-reform period. The impact becomes significantly larger, in absolute terms, when considering the ID group. The reform has reduced the number of new polluting firms by $10 \%$ (530 unborn firms) in sectors belonging to the ID group. Overall, this suggests a $12 \%$ decrease in the number of new polluting firms across both groups.

Some simple correlations suggest that lower enforcing states tend to be poorer and with lower levels of education. If differences in the stringency of the EIA process were to trigger a strategic response from polluting firms intending to enjoy less strict assessments, these states could benefit from the increased comparative advantage in polluting sectors (Kahn and Mansur, 2013). Nevertheless, the negative consequences of pollution on health and related socio-economic outcomes, as described in Graff Zivin and Neidell (2013), could be substantial and could significantly offset the benefits.

Unfortunately, it is not possible to produce welfare considerations or infer the overall impact of the reform on pollution as this would require pollution data on both accepted and $\mathrm{r} E_{j}$ ected projects, and on previously established firms. The pre-reform EIA was considered to be relatively lax (Jha-Thakur, 2011) and given the anecdotal evidence on the proliferation of unchecked polluting firms, the results show that the reform has been successful in limiting the creation of new polluting activities. Nevertheless, pre-existing firms could now pollute more or stay in business longer as a result of a decrease in firm births with negative implications for the

\footnotetext{
${ }^{10}$ Using actual data on employees, turnover or assets from the Orbis dataset was not possible given the high number of missing data-points in these variables.
} 
environment. While firm entry is likely to be directly affected by the reform, as it increases initial sunk costs, the study of firm exit could also provide useful insights. Various hypothesis can be formulated about the impact of the reform on exit. On the one hand, as mentioned earlier, if the reform reduces competition from new firms it could reduce exits. On the other hand, however, because modernization and expansion projects are also subjected to the new regulation, it could also negatively affect survival. Unfortunately, while the date of entry is clearly indicated in the firm registration code (CIN), exit is not easily identifiable in the dataset and could be confounded with temporary closure or lack of reporting. I, therefore, have to defer these issues to future research with more accurate information on exits.

It is also worth noting that the decentralization process has so far only involved sectors with relatively lower polluting capacity. This has important implications for both the extent of the impact of the current reform and a possible further expansion of the decentralization process towards more polluting sectors. On the one hand, the impact of the examined decentralization process on pollution might be small given the relatively lower pollution intensity of the affected sectors. On the other hand, expanding the process to sectors with greater polluting potential could either lead to an even greater reduction in firm births since abatement costs are substantially higher for these activities or, for the same reason, a greater spatial relocation towards low enforcing states. The impact on firm births and pollution of a further expansion of the reform is, therefore, ambiguous.

\subsection{Informality}

Although the analysis considers only registered firms, the presence of a large informal economy raises the concern that the estimated decline in firm births could have translated into an increase in informality, which implies no gains in terms of pollution reduction. Moreover, the presence of informality in some sectors more than in others might have affected the results. In an attempt to provide some empirical evidence on the role of informality, I gathered data on the incidence of informality by sectors from Nataraj (2010). Although the latest information refers to 1999 (table A.9 of the Appendix), it is reasonable to expect that the broad categorization into low and high informality sectors did not substantially change over a decade. I then decomposed the results by sector for the group State and ID, where both high and low informality sectors are present. The Capacity and Central groups are instead mainly characterized by sectors with low incidence of informality. Results are reported in Table 8 and show a greater negative impact of enforcement in sectors with low levels of informality. First, these results suggest that the observed differences between the untreated (Central) and treated groups are not driven by a larger presence of highly informal sectors in the latter groups. Second, this suggestive evidence could point towards an actual decrease in firm births rather than an increase in informality since enforcement is found to affect firm births in sectors where switching to informality is a less feasible option. The Factories Act of 1948 requires all firms with more than 10 employees to register $(20$ workers if not using electricity). Most sectors showing low-level of informality tend to be more capital-good oriented and/or characterized by larger production scales that facilitate detection by the authorities and would also unlikely avoid public scrutiny in terms of environmental impact. Informality, however, could also be driven by economic convenience considerations that could be altered by the reform. A stricter EIA procedure, for example, could impose a higher burden on new firms sufficient to justify informality, and so the avoidance of environmental compliance costs, even in sectors where it is a less common practice. Nevertheless, La Porta and Shleifer (2014), by comparing formal and informal firms in several countries including India, find that formal firms are quite distinct from informal ones and hardly any of the formal firms had ever been informal. Formal entrepreneurs 
Table 8: Impact of the EIA reform by sector with low and high informality

\begin{tabular}{|c|c|c|c|c|}
\hline $\begin{array}{l}\text { Dependent Variable: } \\
\text { Method: }\end{array}$ & $\begin{array}{l}\text { Log (new) } \\
\text { OLS }\end{array}$ & $\begin{array}{l}\text { New } \\
\text { Poisson }\end{array}$ & $\begin{array}{l}(1998-2012) \\
\text { Number of births }\end{array}$ & Type \\
\hline$D_{t} \mathrm{X} E_{j}$ & $\begin{array}{c}0.019 \\
(0.035)\end{array}$ & $\begin{array}{l}-0.037 \\
(0.033)\end{array}$ & 58823 & - \\
\hline$D_{t} \mathrm{X} E_{j} \mathrm{X}$ Central (A) & $\begin{array}{c}0.045 \\
(0.032)\end{array}$ & $\begin{array}{l}0.004 \\
(0.034)\end{array}$ & 4311 & Low informality \\
\hline$D_{t} \mathrm{X} E_{j} \mathrm{X}$ Capacity (A/B) & $\begin{array}{c}0.020 \\
(0.027)\end{array}$ & $\begin{array}{l}-0.016 \\
(0.071)\end{array}$ & 63394 & Low informality \\
\hline \multicolumn{5}{|l|}{ ID $(\mathrm{A} / \mathrm{B})$} \\
\hline$D_{t} \mathrm{X} E_{j}$ X Plastic (2413) & $\begin{array}{l}-0.084 \\
(0.067)\end{array}$ & $\begin{array}{c}-0.135^{* *} \\
(0.066)\end{array}$ & 410 & Low informality \\
\hline$D_{t} \mathrm{X} E_{j} \mathrm{X}$ Fur $(182)$ & $\begin{array}{l}-0.055 \\
(0.128)\end{array}$ & $\begin{array}{l}0.133 \\
(0.123)\end{array}$ & 561 & High informality \\
\hline$D_{t} \mathrm{X} E_{j} \mathrm{X}$ Leather (1911) & $\begin{array}{c}0.044 \\
(0.137)\end{array}$ & $\begin{array}{l}-0.042 \\
(0.190)\end{array}$ & 427 & High informality \\
\hline$D_{t} \mathrm{X} E_{j}$ X Pharma (2423) & $\begin{array}{l}-0.014 \\
(0.032)\end{array}$ & $\begin{array}{l}-0.017 \\
(0.036)\end{array}$ & 7838 & Low informality \\
\hline$D_{t} \mathrm{X} E_{j} \mathrm{X}$ Chemicals (2411) & $\begin{array}{c}-0.182^{* * * *} \\
(0.055)\end{array}$ & $\begin{array}{l}-0.064 \\
(0.058)\end{array}$ & 1759 & Low informality \\
\hline \multicolumn{5}{|l|}{ State (A): } \\
\hline$D_{t} \mathrm{X} E_{j} \mathrm{X}$ Sugar (1542) & $\begin{array}{l}-0.122 \\
(0.111)\end{array}$ & $\begin{array}{c}0.066 \\
(0.079)\end{array}$ & 350 & High informality \\
\hline$D_{t}$ X $E_{j}$ X Paper (2101) & $\begin{array}{c}-0.151^{* *} \\
(0.066)\end{array}$ & $\begin{array}{l}-0.038 \\
(0.090)\end{array}$ & 1192 & Low informality \\
\hline$D_{t}$ X $E_{j}$ X Paints (2422) & $\begin{array}{c}-0.243^{* * *} \\
(0.063)\end{array}$ & $\begin{array}{c}-0.171 * * * \\
(0.061)\end{array}$ & 513 & Low informality \\
\hline $\begin{array}{l}\text { State-sector FE } \\
\text { Year FE }\end{array}$ & $\begin{array}{l}\text { Yes } \\
\text { Yes }\end{array}$ & $\begin{array}{l}\text { Yes } \\
\text { Yes }\end{array}$ & & \\
\hline $\begin{array}{l}\text { Observations } \\
\text { Sector-state }\end{array}$ & $\begin{array}{c}11513 \\
1411\end{array}$ & $\begin{array}{c}20670 \\
1411\end{array}$ & & \\
\hline
\end{tabular}

Standard errors clustered at the state level in parentheses. ${ }^{*} p<0.1,{ }^{* *} p<0.05,{ }^{* * *} p<0.01$.

This table reports only the relevant interactions terms. $D_{t}$ is a dummy indicating the period following the year reported on the column header and $E_{j}$ is the enforcement index at statelevel. These are interacted with category dummies (Central, Capacity) and sector dummies for sector belonging to the ID and State category. The omitted category is "No EIA" (non-polluting firms). The sector 2430 was omitted because of limited firm births (77).

are usually more educated and productive, and are willing to bear the cost of government regulation in order to advertise their products, raise outside capital, and access public goods. In contrast, less able entrepreneurs would not be able to offset the costs from taxes and regulations. Still, EIA-related costs could drive informality choices of firms at the margin. Overall, because of the highlighted differences between formal and informal businesses, a stricter EIA is likely to lead only relatively few firms to choose the informality option, which are not expected to significantly drive the results.

\section{Conclusions}

The decentralization of environmental regulation and enforcement has the potential to lead to a more efficient and transparent system of pollution control and management. On the other hand, it carries the risk of inducing a race-to-the bottom competition among local authorities and to suffer from the consequences of heterogeneous financial and technical constraints across states. The 2006 reform of the EIA process in India has provided a useful setting to test these hypotheses in a context where environmental enforcement varies notably across states. 
This paper has investigated whether the decentralization of the EIA process in India, initiated in 2006, has affected firms' behavior across the country. By considering all registered manufacturing and energy companies, the analysis covers the entire formal economy. The results show that the reform has produced a significant change in firm births in polluting sectors and has led to a relative decrease in birth rates in states with higher enforcement levels. The results are robust to different specifications and are not driven by pre- or post- reform shocks or trends. They are also suggestive of an actual decrease in the number of new polluting firms rather than a switch to informality that would imply no gains in terms of environmental benefits.

A stricter EIA process implies that fewer firms are given permission to operate. The findings indicate that the decentralization process has led to an increase in the average regulatory stringency and has been successful in reducing the number of polluting activities. The effects, however, have not been equally distributed and have only accrued to high-enforcing states. If the regulatory gap between low and high enforcing states is maintained, the reform could, however, potentially trigger an opportunistic behavior by poorer and less developed low-enforcing states aimed at attracting new polluting industry. While the economic gains could be substantial, the health and environmental consequence could also be considerable. This has important implications for future amendments of the EIA regulation that should not ignore the great disparities in environmental enforcement across states. Assistance in the form of training programs or funding, for example, could be provided to states that face technical or financial constraints.

\section{References}

Badiani, R., K. K. Jessoe, and S. Plant (2012). Development and the environment: The implications of agricultural electricity subsidies in India. The Journal of Environment and Development 21(2), 244-262.

Becker, R. and V. Henderson (2000). Effects of air quality regulations on polluting industries. Journal of Political Economy 108(2), 379-421.

Bertrand, M., E. Duflo, and S. Mullainathan (2004, February). How much should we trust differences-in-differences estimates? The Quarterly Journal of Economics 119(1), 249-275.

Besley, T. and S. Coate (2003). Centralized versus decentralized provision of local public goods: A political economy approach. Journal of Public Economics 87(12), 2611 - 2637.

Brunnermeier, S. B. and A. Levinson (2004). Examining the evidence on environmental regulations and industry location. The Journal of Environment 8 Development 13(1), 6-41.

Cistulli, V. (2002). Environment in Decentralized Development: Economic and Institutional issues. Training Materials for Agricultural plannings no. 44. FAO, Rome.

CMS (2005). India Corruption Study 2005 to improve governance. Transparency Internation India.

Dean, J. M., M. E. Lovely, and H. Wang (2009, September). Are foreign investors attracted to weak environmental regulations? Evaluating the evidence from China. Journal of Development Economics 90(1), 1-13. 
Duflo, E., M. Greenstone, R. Pande, and N. Ryan (2013). Truth-telling by third-party auditors and the response of polluting firms: Experimental evidence from India. The Quarterly Journal of Economics 128(4), 1499.

Duvivier, C. and H. Xiong (2013). Transboundary pollution in China: A study of polluting firms' location choices in Hebei province. Environment and Development Economics 18(04), 459-483.

Giovannini, E., M. Nardo, M. Saisana, A. Saltelli, S. Tarantola, and A. Hoffman (2005). Handbook on constructing composite indicators: Methodology and user guide. Technical report, OECD Statistics Working Paper.

Government of India (Various years (1998-2012)). Annual survey of industries. Technical report, Ministry of Statistics and Programme implementation, Central Statistics Office.

Graff Zivin, J. and M. Neidell (2013). Environment, health, and human capital. Journal of Economic Literature 51(3), 689-730.

Greenstone, M. and R. Hanna (2014). Environmental regulations, air and water pollution, and infant mortality in India. American Economic Review 104(10), 3038-72.

Greenstone, M. and B. K. Jack (2015). Envirodevonomics: A research agenda for a young field. Journal of Economic Literature 53(1), 5-42.

Javorcik, B. S. and S.-J. Wei (2003). Pollution havens and foreign direct investment: Dirty secret or popular myth? The B.E. Journal of Economic Analysis 8 Policy 3(2), 1-34.

Jha-Thakur, U. (2011). Environmental impact assessment follow-up in India: Exploring regional variation. Journal of Environmental Assessment Policy and Management 13(03), 435-458.

Kahn, M. E. and E. T. Mansur (2013). Do local energy prices and regulation affect the geographic concentration of employment? Journal of Public Economics 101(0), 105 - 114.

Kalemli-Ozcan, S., B. Sorensen, C. Villegas-Sanchez, V. Volosovych, and S. Yesiltas (2015). How to construct nationally representative firm level data from the orbis global database. Technical report, National Bureau of Economic Research.

Kathuria, V. (2007). Informal regulation of pollution in a developing country: Evidence from India. Ecological Economics 63(23), 403 - 417.

La Porta, R. and A. Shleifer (2014). Informality and development. The Journal of Economic Perspectives 28(3), 109-126.

Lal, P. and V. Jha (1999). Judicial activism and the environment in India. implications for transnational. Occasional paper no. 6, UNCATD/CBS Project: Cross Border Environmental Management in Transnational Corporations.

Lipscomb, M. (2008). The erfect of environmental enforcement on product choice and competition. theory and evidence from India. Working paper no. 08-13, Center for Economic Analysis, University of Colorado at Boulder.

Lipscomb, M. and A. M. Mobarak (2016). Decentralization and the political economy of water pollution: Evidence from the re-drawing of county borders in Brazil. The Review of Economic Studies, forthcoming. 
List, J. A., D. L. Millimet, P. G. Fredriksson, and W. W. McHone (2003). Effects of environmental regulations on manufacturing plant births: Evidence from a propensity score matching estimator. The Review of Economics and Statistics 85(4), pp. 944-952.

Mani, M., S. Pargal, and M. Huq (1997). Is there an environmental "race to the bottom"? Evidence on the role of environmental regulation in plant location decisions in India. Technical report, The World Bank.

Nandimath, O. V. (2009). Handbook of Environmental Decision Making in India: And EIA model. New Delhi, India: Oxford University Press.

Nataraj, S. (2010). Productivity and Firm Size Distribution: Evidence from India's Organized and Unorganized Manufacturing Sectors. Ph. D. thesis, University of California, Berkeley.

OECD (2006). Environmental compliance and enforcement in India: Rapid assessment. Technical report, OECD, Paris.

Panigrahi, J. K. and S. Amirapu (2012). An assessment of EIA system in India. Environmental Impact Assessment Review 35(0), 23 - 36.

Sigman, H. (2005). Transboundary spillovers and decentralization of environmental policies. Journal of Environmental Economics and Management 50(1), 82 - 101.

UNESCAP (2000). State of environment in Asia and the Pacific. Technical report, Asian Development Bank and United Nations.

Wooldridge, J. M. (1991). Specification testing and quasi-maximum-likelihood estimation. Journal of Econometrics (48), 29-55.

World Bank (2006). India, strengthening institutions for sustainable growth: Country environmental analysis. Technical report, Report No. 38292-IN, South Asia Environment and Social Development Unit, the World Bank, Washington D.C. 


\section{Appendix}

Table A.1: Activities listed in the EIA notification, their categorization and the corresponding NIC classification

\begin{tabular}{|c|c|c|c|c|}
\hline Project or Activity & NIC 3 digit & $\mathrm{A}$ & $\mathrm{B}$ & Group \\
\hline \multicolumn{5}{|c|}{$\begin{array}{l}\text { Mining, extraction of natural resources and power generation } \\
101, \quad 102,>50 \text { ha. of mining }\end{array}$} \\
\hline Mining of minerals & $\begin{array}{ll}120, & 131 \\
132, & 141 \\
142 & \end{array}$ & $\begin{array}{l}\text { lease area; Asbestos } \\
\text { mining irrespective of } \\
\text { mining area }\end{array}$ & $\begin{array}{l}<50 \text { ha; } 5 \text { ha of mining } \\
\text { lease area. }\end{array}$ & Capacity \\
\hline $\begin{array}{l}\text { Offshore and onshore oil and } \\
\text { gas exploration, development } \\
\text { and production }\end{array}$ & 111,112 & All projects & & Central \\
\hline River Valley projects & 401,452 & $\begin{array}{l}\text { (i) > 50 MW hydro- } \\
\text { electric power genera- } \\
\text { tion; (ii) > 10,000 ha. } \\
\text { of culturable command } \\
\text { area }\end{array}$ & $\begin{array}{l}\text { (i) }<50 \text { MW }>25 \\
\text { MW } \quad \text { hydroelectric } \\
\text { power generation; } \\
\text { (ii) }<10,000 \text { ha. of } \\
\text { culturable command } \\
\text { area }\end{array}$ & Capacity \\
\hline Thermal Power Plants & 401 & $\begin{array}{l}500 \mathrm{MW} \text { (coal/ lignite/ } \\
\text { naphta and gas based); } \\
50 \mathrm{MW} \text { (Pet coke diesel } \\
\text { and all other fuels) }\end{array}$ & $\begin{array}{l}<500 \text { MW (coal/ } \\
\text { lignite/ naptha and } \\
\text { gas based); <50 MW; } \\
\geq 5 \mathrm{MW} \text { (Pet coke } \\
\text {,diesel and all other } \\
\text { fuels) }\end{array}$ & Capacity \\
\hline $\begin{array}{l}\text { Nuclear power projects and } \\
\text { processing of nuclear fuel }\end{array}$ & $\begin{array}{l}401,452 \\
233\end{array}$ & All projects & & Central \\
\hline \multicolumn{5}{|l|}{ Primary Processing } \\
\hline Coal washeries & 101,102 & $\begin{array}{l}\geq 1 \text { million ton/ an- } \\
\text { num throughput of } \\
\text { coal }\end{array}$ & $\begin{array}{l}<1 \text { million ton / annum } \\
\text { throughput of coal }\end{array}$ & Capacity \\
\hline Mineral beneficiation & - & $\begin{array}{l}\geq 0.1 \text { million ton/ an- } \\
\text { num mineral through- } \\
\text { put }\end{array}$ & $\begin{array}{l}<0.1 \text { million ton/ an- } \\
\text { num mineral through- } \\
\text { put }\end{array}$ & Capacity \\
\hline \multicolumn{5}{|l|}{ Materials Production } \\
\hline $\begin{array}{l}\text { Metallurgical industries (fer- } \\
\text { rous and non ferrous) }\end{array}$ & 271,272 & $\begin{array}{l}\text { a)Primary metallur- } \\
\text { gical industry: All } \\
\text { projects; b) Sponge } \\
\text { iron manufacturing: } \geq \\
\text { 200TPD; c) Secondary } \\
\text { metallurgical process- } \\
\text { ing industry: All toxic } \\
\text { and heavy } \geq 20,000 \\
\text { tonnes / annummetal } \\
\text { producing units }\end{array}$ & $\begin{array}{l}\text { Sponge iron man- } \\
\text { ufacturing: < } 200 \\
\text { TPD; Secondary met- } \\
\text { allurgical processing } \\
\text { industry: i) All toxic } \\
\text { and heavy metal pro- } \\
\text { ducing units: }<20,000 \\
\text { tonnes /annum; ii) All } \\
\text { other non-toxic sec- } \\
\text { ondary metallurgical } \\
\text { processing industries } \\
>5000 \text { tonnes/annum }\end{array}$ & Capacity \\
\hline Cement plants & 269 & $\begin{array}{l}1.0 \text { million tonnes/ an- } \\
\text { num production capac- } \\
\text { ity }\end{array}$ & $\begin{array}{l}<1.0 \text { million tonnes/ } \\
\text { annum production ca- } \\
\text { pacity. All Stand alone } \\
\text { grinding units }\end{array}$ & Capacity \\
\hline $\begin{array}{l}\text { Materials Processing } \\
\text { Petroleum refining industry }\end{array}$ & 232 & All projects & & Central \\
\hline Coke oven plants & 231 & $\begin{array}{l}\geq 2,50,000 \text { tonnes/ an- } \\
\text { num }\end{array}$ & $\begin{array}{l}<2,50,000 \text { and } \geq \\
25,000 \text { tonnes } / \text { annum }\end{array}$ & Capacity \\
\hline $\begin{array}{l}\text { Asbestos milling and asbestos } \\
\text { based products }\end{array}$ & 269,142 & All projects & & Central \\
\hline
\end{tabular}




\begin{tabular}{lcllc}
\hline Soda ash Industry & - & All projects & Central \\
\hline Leather/skin/hide processing & 1911,182 & $\begin{array}{l}\text { New projects outside } \\
\text { the Industrial district } \\
\text { or expansion of existing } \\
\text { units out side the In- } \\
\text { dustrial district }\end{array}$ & $\begin{array}{l}\text { All new or expansion of } \\
\text { projects located within } \\
\text { district/ district }\end{array}$ & $\begin{array}{l}\text { Industrial } \\
\text { district }\end{array}$ \\
\hline $\begin{array}{l}\text { Manufacturing/Fabrication } \\
\text { Chemical fertilizers }\end{array}$ & 2412 & \multicolumn{1}{c}{ All projects } & Central \\
\hline Pesticides industry & 2421 & $\begin{array}{l}\text { All units produc- } \\
\text { ing technical grade } \\
\text { pesticides }\end{array}$ & Central \\
\hline
\end{tabular}

Petrochemical complexes (industries based on processing of petroleum fractions and natural gas and/or reforming to aromatics)

\begin{tabular}{|c|c|c|c|c|}
\hline Manmade fibres manufacturing & 2430 & Rayon & Others & State \\
\hline $\begin{array}{l}\text { Petrochemical based process- } \\
\text { ing (processes other than } \\
\text { cracking and reformat not } \\
\text { covered under complexes) }\end{array}$ & - & $\begin{array}{l}\text { Located out side the } \\
\text { notified Industrial dis- } \\
\text { trict/ district }\end{array}$ & $\begin{array}{l}\text { Located in a notified } \\
\text { Industrial district/ dis- } \\
\text { trict }\end{array}$ & $\begin{array}{l}\text { Industrial } \\
\text { district }\end{array}$ \\
\hline $\begin{array}{l}\text { Synthetic organic chemicals in- } \\
\text { dustry (dyes and dye; interme- } \\
\text { diates; bulk drugs and interme- } \\
\text { diates; synthetic rubbers; basic } \\
\text { organic chemicals, other syn- } \\
\text { thetic organic chemicals and } \\
\text { chemical intermediates includ- } \\
\text { ing pesticides intermediates) }\end{array}$ & $\begin{array}{l}2411,2413 \\
2423\end{array}$ & $\begin{array}{l}\text { Located out side the } \\
\text { notified Industrial dis- } \\
\text { trict/ district }\end{array}$ & $\begin{array}{l}\text { Located in a notified } \\
\text { Industrial district/ dis- } \\
\text { trict }\end{array}$ & $\begin{array}{l}\text { Industrial } \\
\text { district }\end{array}$ \\
\hline Distilleries & 155 & $\begin{array}{l}\text { (i) All } \begin{array}{r}\text { Molasses } \\
\text { based } \\
\text { (ii) All Cantilleries; }\end{array} \\
\text { non-molasses based } \\
\text { distilleries } \geq 30 \text { KLD } \\
\end{array}$ & $\begin{array}{l}\text { All Cane juice/non- } \\
\text { molasses based distil- } \\
\text { leries }<30 \mathrm{KLD}\end{array}$ & Capacity \\
\hline Integrated paint industry & 2422 & All projects & & State \\
\hline $\begin{array}{l}\text { Pulb and paper industry ex- } \\
\text { cluding manufacturing of pa- } \\
\text { per waste from paper and man- } \\
\text { ufacture of paper from ready } \\
\text { pulp with out bleaching }\end{array}$ & 2101,2102 & Pulp manufacturing & $\begin{array}{l}\text { Paper manufacturing } \\
\text { without pulp }\end{array}$ & State \\
\hline Sugar Industry & 1542 & & $\begin{array}{l}\geq 5000 \text { tcd cane crush- } \\
\text { ing capacity }\end{array}$ & State \\
\hline
\end{tabular}


Table A.2: Date of constitution of State EIA Authority

\begin{tabular}{lr}
\hline State & Date of constitution of SEIAA \\
\hline Andhra Pradesh & 4th July 2007 \\
Arunachal Pradesh & 27th March 2008 \\
Bihar & 7th February 2011 \\
Chandigarh & 21st August 2009 \\
Chhattisgarh & 9th January 2008 \\
Dadra and Nagar Haveli & 11th October 2007 \\
Daman \& Diu & 11th October 2007 \\
Delhi & 30th July 2008 \\
Goa & 15th April 2010 \\
Gujarat & 12th June 2007 \\
Haryana & 21st April 2008 \\
Himachal Pradesh & 11th October 2007 \\
Jammu and Kashmir & 8th January 2008 \\
Jharkhand & 20th December 2012 \\
Karnataka & 11th June 2007 \\
Kerala & 3rd November 2011 \\
Madhya Pradesh & 8th January 2008 \\
Maharashtra & 21st April 2008 \\
Meghalaya & 23rd July 2007 \\
Nagaland & 15th April 2010 \\
Orissa & November 2008 \\
Puducherry & 17th \\
Punjab & 13th December 2007 \\
RE asthan & 19th November 2007 \\
Sikkim & 30th July 2008 \\
Tamil Nadu & 8th July 2008 \\
Uttar Pradesh & 3rd March 2008 \\
Uttarakhand & 12th July 2007 \\
West Bengal & 13th April 2007 \\
\hline
\end{tabular}

Table A.3: Sectors excluded from the analysis because of ambiguities in their classification

\begin{tabular}{ll}
\hline NIC code & Description \\
\hline 103 & Extraction and agglomeration of peat [incl. digging of peat] \\
181 & Manufacture of wearing apparel, except fur apparel \\
192 & Manufacture of footwear. \\
261 & Manufacture of glass and glass products \\
281 & Manufacture of structural metal products, tanks, reservoirs and steam generators \\
289 & Manufacture of other fabricated metal products; metal working service activities \\
2420 & Manufacture of basic chemicals \\
2424 & Manufacture of other chemical products \\
2429 & Manufacture of soap and detergents \\
2109 & Manufacture of other chemical product n.e.c. \\
\hline
\end{tabular}


Table A.4: Number of new firms by category and state

\begin{tabular}{lcccccc}
\hline State & Without EIA & Large & Central-level & ID & State-level & Total \\
\hline Andhra Pradesh & 3281 & 326 & 4909 & 1406 & 185 & 6826 \\
Assam & 301 & 52 & 488 & 27 & 16 & 583 \\
Bihar & 454 & 30 & 1733 & 124 & 14 & 1901 \\
Chandigarh & 326 & 16 & 325 & 180 & 18 & 539 \\
Chhattisgarh & 265 & 56 & 1041 & 49 & 8 & 1154 \\
Delhi & 11984 & 512 & 12018 & 1823 & 440 & 14793 \\
Goa & 207 & 14 & 258 & 28 & 10 & 310 \\
Gujarat & 6200 & 803 & 4110 & 1346 & 171 & 6430 \\
Haryana & 1349 & 61 & 743 & 200 & 40 & 1044 \\
Himachal Pradesh & 134 & 10 & 514 & 83 & 10 & 617 \\
Jammu \& Kashmir & 123 & 12 & 177 & 24 & 5 & 218 \\
Jharkhand & 242 & 29 & 1053 & 39 & 3 & 1124 \\
Karnataka & 3474 & 169 & 3291 & 407 & 136 & 4003 \\
Kerala & 1179 & 96 & 1639 & 274 & 46 & 2055 \\
Madhya Pradesh & 1075 & 164 & 2065 & 387 & 57 & 2673 \\
Maharashtra & 12822 & 875 & 11306 & 2061 & 498 & 14740 \\
Meghalaya & 48 & 13 & 170 & 7 & 3 & 193 \\
Odisha & 531 & 78 & 2165 & 91 & 19 & 2353 \\
Puducherry & 89 & 6 & 86 & 33 & 6 & 131 \\
Punjab & 1202 & 78 & 858 & 197 & 46 & 1179 \\
Rajasthan & 1919 & 186 & 4711 & 435 & 66 & 5398 \\
Tamil Nadu & 5185 & 266 & 3898 & 652 & 173 & 4989 \\
Uttar Pradesh & 2121 & 135 & 1776 & 668 & 56 & 2635 \\
Uttarakhand & 217 & 19 & 163 & 50 & 4 & 236 \\
West Bengal & 4095 & 305 & 3897 & 404 & 102 & 4708 \\
Total & 58823 & 4311 & 63394 & 10995 & 2132 & 139655 \\
\hline Source: author's cal & & & & &
\end{tabular}

Source: author's calculations based on Orbis dataset.

Figure 3: Number of new firms by groups and year

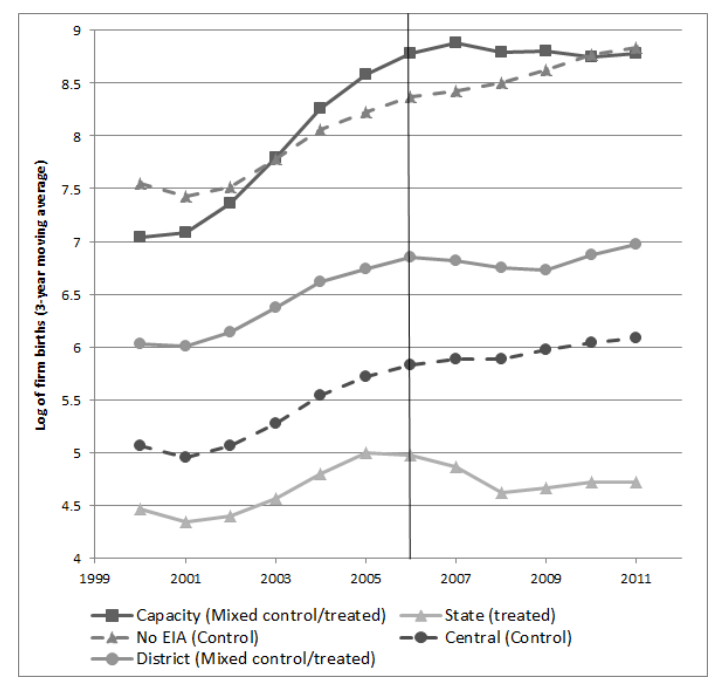

Author's calculation based on the Orbis database. The plots are based on 3-year moving averages. 
Table A.5: Impact of the EIA reform by groups: date of creation of state-level EIA Authorities

\begin{tabular}{|c|c|c|}
\hline $\begin{array}{l}\text { Dependent variable: } \\
\text { Method: }\end{array}$ & $\begin{array}{c}(1) \\
\log (\text { new firms) } \\
\text { OLS }\end{array}$ & $\begin{array}{l}(2) \\
\text { New firms } \\
\text { Poisson }\end{array}$ \\
\hline$D_{t}$ x Central (A) & $\begin{array}{c}-0.158^{* *} \\
(0.069)\end{array}$ & $\begin{array}{l}-0.112 \\
(0.080)\end{array}$ \\
\hline$D_{t}$ x Capacity $(\mathrm{A} / \mathrm{B})$ & $\begin{array}{l}0.008 \\
(0.049)\end{array}$ & $\begin{array}{l}-0.016 \\
(0.093)\end{array}$ \\
\hline$D_{t} \times \mathrm{ID}(\mathrm{A} / \mathrm{B})$ & $\begin{array}{c}0.086 \\
(0.091)\end{array}$ & $\begin{array}{l}-0.185 \\
(0.123)\end{array}$ \\
\hline$D_{t} \mathrm{x}$ State $(\mathrm{B})$ & $\begin{array}{l}-0.011 \\
(0.069)\end{array}$ & $\begin{array}{l}-0.121 \\
(0.113)\end{array}$ \\
\hline$D_{t} \times E_{j}$ & $\begin{array}{c}0.006 \\
(0.031)\end{array}$ & $\begin{array}{l}-0.059^{*} \\
(0.034)\end{array}$ \\
\hline$D_{t} \times E_{j} \times$ Central $(\mathrm{A})$ & $\begin{array}{c}0.034 \\
(0.037)\end{array}$ & $\begin{array}{c}0.008 \\
(0.029)\end{array}$ \\
\hline$D_{t} \times E_{j} \times$ Capacity $(\mathrm{A} / \mathrm{B})$ & $\begin{array}{l}-0.019 \\
(0.024)\end{array}$ & $\begin{array}{c}0.026 \\
(0.051)\end{array}$ \\
\hline$D_{t} \times E_{j} \times \mathrm{ID}(\mathrm{A} / \mathrm{B})$ & $\begin{array}{l}-0.089^{*} \\
(0.051)\end{array}$ & $\begin{array}{c}-0.084^{* *} \\
(0.039)\end{array}$ \\
\hline$D_{t} \times E_{j} \times$ State $(\mathrm{B})$ & $\begin{array}{c}-0.129 * * \\
(0.055)\end{array}$ & $\begin{array}{l}-0.062 \\
(0.076)\end{array}$ \\
\hline $\begin{array}{l}\text { Sector-state FE } \\
\text { Year FE }\end{array}$ & $\begin{array}{l}\text { Yes } \\
\text { Yes } \\
\end{array}$ & $\begin{array}{l}\text { Yes } \\
\text { Yes } \\
\end{array}$ \\
\hline $\begin{array}{l}\text { Observations } \\
\text { State-sectors }\end{array}$ & $\begin{array}{l}11709 \\
1392\end{array}$ & $\begin{array}{c}21165 \\
1392\end{array}$ \\
\hline \multicolumn{3}{|c|}{ P-value of t-test for coefficients of triple interactions } \\
\hline Central = Capacity & 0.101 & 0.685 \\
\hline Central $=$ ID & 0.006 & 0.046 \\
\hline Central $=$ State & 0.020 & 0.323 \\
\hline
\end{tabular}

Standard errors clustered at the state level in parentheses. ${ }^{*} p<0.1,{ }^{* *} p<0.05$, *** $p<0.01$ This table reports only the relevant interactions terms. Estimates refer to most comprehensive specification. $D_{t}$ is a dummy indicating the period after the creation of EIA authorities and $E_{j}$ is enforcement at state-level. These are interacted with category dummies: Central, Capacity, ID and State. The omitted category is "No EIA" (non-polluting firms). The enforcement measure used in each specification is indicated in the column header. 
Table A.6: Results using alternative enforcement index

\begin{tabular}{|c|c|c|c|c|}
\hline \multirow[b]{2}{*}{$\begin{array}{l}\text { Depend variable: } \\
\text { Method: }\end{array}$} & \multicolumn{2}{|c|}{ (1) PCA: ratios } & \multicolumn{2}{|c|}{$\begin{array}{c}\text { (3) } \\
\text { Equal weights } \\
\text { to standardized variables }\end{array}$} \\
\hline & $\begin{array}{l}\log (\text { new firms) } \\
\text { OLS }\end{array}$ & $\begin{array}{l}\text { New firms } \\
\text { Poisson }\end{array}$ & $\begin{array}{c}\text { Log (new firms) } \\
\text { OLS }\end{array}$ & $\begin{array}{l}\text { New firms } \\
\text { Poisson }\end{array}$ \\
\hline$D_{t} \times$ Central & $\begin{array}{c}-0.252^{* * *} \\
(0.067)\end{array}$ & $\begin{array}{l}-0.180 \\
(0.112)\end{array}$ & $\begin{array}{c}-0.272^{* * *} \\
(0.066)\end{array}$ & $\begin{array}{l}-0.204^{*} \\
(0.108)\end{array}$ \\
\hline$D_{t} \mathrm{x}$ Capacity $(\mathrm{A} / \mathrm{B})$ & $\begin{array}{c}0.396^{* * * *} \\
(0.080)\end{array}$ & $\begin{array}{c}0.268^{* *} \\
(0.127)\end{array}$ & $\begin{array}{c}0.385^{* * * *} \\
(0.081)\end{array}$ & $\begin{array}{c}0.250^{* *} \\
(0.117)\end{array}$ \\
\hline$D_{t} \times \mathrm{ID}(\mathrm{A} / \mathrm{B})$ & $\begin{array}{c}0.060 \\
(0.086)\end{array}$ & $\begin{array}{l}-0.014 \\
(0.146)\end{array}$ & $\begin{array}{c}0.070 \\
(0.083)\end{array}$ & $\begin{array}{c}0.059 \\
(0.139)\end{array}$ \\
\hline$D_{t} \times$ State $(\mathrm{B})$ & $\begin{array}{l}-0.050 \\
(0.052)\end{array}$ & $\begin{array}{l}-0.137 \\
(0.115)\end{array}$ & $\begin{array}{l}-0.032 \\
(0.054)\end{array}$ & $\begin{array}{l}-0.105 \\
(0.123)\end{array}$ \\
\hline$D_{t} \times E_{j}$ & $\begin{array}{l}0.068^{*} \\
(0.037)\end{array}$ & $\begin{array}{l}-0.037 \\
(0.043)\end{array}$ & $\begin{array}{c}0.145 \\
(0.109)\end{array}$ & $\begin{array}{l}-0.141 \\
(0.117)\end{array}$ \\
\hline$D_{t} \times E_{j} \times$ Central (A) & $\begin{array}{c}0.015 \\
(0.046)\end{array}$ & $\begin{array}{c}0.023 \\
(0.050)\end{array}$ & $\begin{array}{c}0.083 \\
(0.119)\end{array}$ & $\begin{array}{c}0.099 \\
(0.133)\end{array}$ \\
\hline$D_{t} \times E_{j} \times$ Capacity $(\mathrm{A} / \mathrm{B})$ & $\begin{array}{c}0.033 \\
(0.033)\end{array}$ & $\begin{array}{l}-0.090 \\
(0.079)\end{array}$ & $\begin{array}{c}0.098 \\
(0.091)\end{array}$ & $\begin{array}{l}-0.181 \\
(0.208)\end{array}$ \\
\hline$D_{t} \times E_{j} \times \mathrm{ID}(\mathrm{A} / \mathrm{B})$ & $\begin{array}{l}-0.078^{*} \\
(0.040)\end{array}$ & $\begin{array}{c}-0.128^{* *} \\
(0.056)\end{array}$ & $\begin{array}{l}-0.208^{*} \\
(0.114)\end{array}$ & $\begin{array}{c}-0.445^{* * * *} \\
(0.147)\end{array}$ \\
\hline$D_{t} \times E_{j} \times$ State $(\mathrm{B})$ & $\begin{array}{c}-0.224^{* * *} \\
(0.051)\end{array}$ & $\begin{array}{l}-0.131^{*} \\
(0.071)\end{array}$ & $\begin{array}{c}-0.568^{* * *} \\
(0.147)\end{array}$ & $\begin{array}{l}-0.366 \\
(0.224)\end{array}$ \\
\hline $\begin{array}{l}\text { Sector-state FE } \\
\text { Year FE }\end{array}$ & $\begin{array}{l}\text { Yes } \\
\text { Yes }\end{array}$ & $\begin{array}{l}\text { Yes } \\
\text { Yes }\end{array}$ & $\begin{array}{l}\text { Yes } \\
\text { Yes }\end{array}$ & \\
\hline $\begin{array}{l}\text { Observations } \\
\text { State-sectors }\end{array}$ & $\begin{array}{c}11709 \\
1411\end{array}$ & $\begin{array}{c}21165 \\
1411\end{array}$ & $\begin{array}{l}11709 \\
1411\end{array}$ & $\begin{array}{c}21165 \\
1411\end{array}$ \\
\hline $\begin{array}{l}\text { P-value of t-test for coeffici } \\
\text { Central = Capacity } \\
\text { Central = ID } \\
\text { Central = State }\end{array}$ & $\begin{array}{l}\text { nts of triple intera } \\
0.495 \\
0.110 \\
0.002\end{array}$ & $\begin{array}{r}\text { tions } \\
0.084 \\
0.038 \\
0.029\end{array}$ & $\begin{array}{l}0.841 \\
0.048 \\
0.001\end{array}$ & $\begin{array}{l}0.138 \\
0.000 \\
0.020\end{array}$ \\
\hline \multicolumn{5}{|c|}{$\begin{array}{l}\text { Standard errors clustered at the state level in parentheses. }{ }^{*} p<0.1,{ }^{* *} p<0.05, * * * \\
p<0.01 \text {. Results are obtained using a alternative enforcement indexes. In Columns } 1 \text { and } \\
2 \text { the index is obtained with principal component analysis and enforcement variables are } \\
\text { divided by the size of the population in each state with the exception of the corruption } \\
\text { index. In Columns } 3 \text { and } 4 \text { the index is obtained by given equal weights to all standardized } \\
\text { variables. This table reports only the relevant interactions terms. Estimates refer to most } \\
\text { comprehensive specification. } D_{t} \text { is a dummy indicating the period after the creation of } \\
\text { EIA authorities and } E_{j} \text { is enforcement at state-level. These are interacted with category } \\
\text { dummies: Central, Capacity, ID and State. The omitted category is "No EIA" (non- } \\
\text { polluting firms). }\end{array}$} \\
\hline
\end{tabular}


Table A.7: Results using bootstrapped standard errors and pre-post treatment averages

\begin{tabular}{|c|c|c|c|c|}
\hline & $\begin{array}{l}\log (\text { new firms) } \\
\text { OLS }\end{array}$ & $\begin{array}{l}\text { New firms } \\
\text { Poisson }\end{array}$ & $\begin{array}{l}\log (\text { new firms) } \\
\text { OLS }\end{array}$ & $\begin{array}{l}\text { New firms } \\
\text { Poisson }\end{array}$ \\
\hline$D_{t} \times$ Central $(\mathrm{A})$ & $\begin{array}{c}-0.161^{* * *} \\
(0.054)\end{array}$ & $\begin{array}{l}-0.193 \\
(0.130)\end{array}$ & $\begin{array}{l}-0.081 \\
(0.089)\end{array}$ & $\begin{array}{l}-0.149^{*} \\
(0.080)\end{array}$ \\
\hline$D_{t} \times$ Capacity $(\mathrm{A} / \mathrm{B})$ & $\begin{array}{l}-0.083 \\
(0.057)\end{array}$ & $\begin{array}{c}0.191 \\
(0.125)\end{array}$ & $\begin{array}{l}-0.082 \\
(0.109)\end{array}$ & $\begin{array}{c}-0.195^{*} \\
(0.112)\end{array}$ \\
\hline$D_{t} \times \operatorname{ID}(\mathrm{A} / \mathrm{B})$ & $\begin{array}{l}0.085 \\
(0.071)\end{array}$ & $\begin{array}{l}-0.077 \\
(0.150)\end{array}$ & $\begin{array}{c}0.213^{* * *} \\
(0.062)\end{array}$ & $\begin{array}{l}-0.041 \\
(0.118)\end{array}$ \\
\hline$D_{t} \times$ State $(\mathrm{B})$ & $\begin{array}{c}0.076 \\
(0.060)\end{array}$ & $\begin{array}{l}-0.133 \\
(0.144)\end{array}$ & $\begin{array}{l}-0.025 \\
(0.079)\end{array}$ & $\begin{array}{c}0.154 \\
(0.138)\end{array}$ \\
\hline$D_{t} \times E_{j}$ & $\begin{array}{c}0.020 \\
(0.039)\end{array}$ & $\begin{array}{l}-0.021 \\
(0.058)\end{array}$ & $\begin{array}{c}0.099 * * \\
(0.036)\end{array}$ & $\begin{array}{c}-0.067^{* *} \\
(0.032)\end{array}$ \\
\hline$D_{t} \times E_{j} \times$ Central (A) & $\begin{array}{c}0.049 \\
(0.036)\end{array}$ & $\begin{array}{l}0.026 \\
(0.067)\end{array}$ & $\begin{array}{c}0.011 \\
(0.039)\end{array}$ & $\begin{array}{l}0.050 \\
(0.063)\end{array}$ \\
\hline$D_{t} \mathrm{x} E_{j} \mathrm{x}$ Capacity $(\mathrm{A} / \mathrm{B})$ & $\begin{array}{c}0.018 \\
(0.025)\end{array}$ & $\begin{array}{l}-0.100 \\
(0.090)\end{array}$ & $\begin{array}{c}0.023 \\
(0.025)\end{array}$ & $\begin{array}{l}-0.108 \\
(0.067)\end{array}$ \\
\hline$D_{t} \mathrm{x} E_{j} \times \mathrm{ID}(\mathrm{A} / \mathrm{B})$ & $\begin{array}{c}-0.080^{* *} \\
(0.041)\end{array}$ & $\begin{array}{l}-0.146^{*} \\
(0.070)\end{array}$ & $\begin{array}{c}-0.123^{* *} \\
(0.045)\end{array}$ & $\begin{array}{c}-0.094^{* *} \\
(0.041)\end{array}$ \\
\hline$D_{t} \times E_{j} \times$ State $(\mathrm{B})$ & $\begin{array}{c}-0.148^{* * * *} \\
(0.057)\end{array}$ & $\begin{array}{l}-0.136 \\
(0.104)\end{array}$ & $\begin{array}{c}-0.116^{* *} \\
(0.054)\end{array}$ & $\begin{array}{c}-0.118^{* *} \\
(0.058)\end{array}$ \\
\hline $\begin{array}{l}\text { State - sector FE } \\
\text { Year FE }\end{array}$ & $\begin{array}{l}\text { Yes } \\
\text { No }\end{array}$ & $\begin{array}{l}\text { Yes } \\
\text { No }\end{array}$ & $\begin{array}{l}\text { Yes } \\
\text { Yes }\end{array}$ & $\begin{array}{l}\text { Yes } \\
\text { Yes }\end{array}$ \\
\hline $\begin{array}{l}\text { Observations } \\
\text { State-sectors }\end{array}$ & $\begin{array}{l}11709 \\
1411\end{array}$ & $\begin{array}{c}21165 \\
1411\end{array}$ & $\begin{array}{l}2528 \\
1411\end{array}$ & $\begin{array}{l}2822 \\
1411\end{array}$ \\
\hline $\begin{array}{l}\text { P-value of t-test for coeffic } \\
\text { Central = Capacity } \\
\text { Central = ID } \\
\text { Central = State }\end{array}$ & $\begin{array}{c}\text { nts of triple inter } \\
0.263 \\
0.002 \\
0.002\end{array}$ & $\begin{array}{l}\text { ctions } \\
0.103 \\
0.068 \\
0.080\end{array}$ & $\begin{array}{l}0.703 \\
0.007 \\
0.046\end{array}$ & $\begin{array}{l}0.072 \\
0.027 \\
0.022\end{array}$ \\
\hline
\end{tabular}

$* p<0.1,{ }^{* *} p<0.05,{ }^{* * *} p<0.01$. This table reports only the relevant interactions terms. All specifications are, however, estimated including all interaction terms as reported in Equation 1. $D_{t}$ is a dummy indicating the post-reform period and $E_{j}$ is enforcement at state-level. These are interacted with category dummies: Central, Capacity, ID and State. The omitted category is "No EIA" (non-polluting firms). Columns 1 and 2 report bootstrapped standard errors using state-level clusters and 500 repetitions. In column 3 and 4 data are averaged over the pre and post period. 
Table A.8: Placebo difference in differences test on pre-reform period

\begin{tabular}{lcccc}
\hline & $(1)$ & $(2)$ & $(3)$ & $(4)$ \\
$D_{t}=$ & 2002 & 2003 & 2004 & 2005 \\
\hline$D_{t} \times$ Central (A) & 0.008 & 0.026 & 0.042 & 0.035 \\
& $(0.909)$ & $(0.783)$ & $(0.600)$ & $(0.715)$ \\
$D_{t} \times$ Capacity (A/B) & 0.055 & 0.058 & 0.042 & 0.033 \\
& $(0.317)$ & $(0.403)$ & $(0.561)$ & $(0.485)$ \\
$D_{t} \times$ ID $(\mathrm{A} / \mathrm{B})$ & 0.062 & 0.019 & -0.037 & 0.046 \\
& $(0.339)$ & $(0.758)$ & $(0.624)$ & $(0.647)$ \\
$D_{t} \times$ State $(\mathrm{B})$ & 0.033 & 0.002 & 0.000 & -0.078 \\
& $(0.676)$ & $(0.987)$ & $(0.999)$ & $(0.554)$ \\
$D_{t} \times E_{j}$ & $0.043^{* * *}$ & $0.049 * * *$ & $0.066^{* * *}$ & $0.056^{* * *}$ \\
& $(0.002)$ & $(0.001)$ & $(0.001)$ & $(0.005)$ \\
$D_{t} \times E_{j} \times$ Central $(\mathrm{A})$ & -0.022 & -0.053 & -0.055 & -0.030 \\
$D_{t} \times E_{j} \times$ Capacity $(\mathrm{A} / \mathrm{B})$ & $(0.541)$ & $(0.139)$ & $(0.211)$ & $(0.469)$ \\
& -0.019 & -0.014 & -0.027 & 0.006 \\
$D_{t} \times E_{j} \times$ ID $(\mathrm{A} / \mathrm{B})$ & $(0.307)$ & $(0.519)$ & $(0.236)$ & $(0.763)$ \\
$D_{t} \times E_{j} \times$ State $(\mathrm{B})$ & -0.028 & -0.017 & 0.011 & 0.029 \\
State - sector FE & $(0.450)$ & $(0.666)$ & $(0.808)$ & $(0.561)$ \\
Year FE & -0.003 & 0.038 & 0.065 & 0.074 \\
\hline Observations & $(0.939)$ & $(0.382)$ & $(0.204)$ & $(0.360)$ \\
\hline
\end{tabular}

Standard errors clustered at the state level in parentheses. ${ }^{*} p<0.1,{ }^{* *}$ $p<0.05,{ }^{* * *} p<0.01$. This table reports only the relevant interactions terms. All specifications are, however, estimated including all interaction terms as reported in Equation 1. They also include the average share of new firms in each state-year and the total number of new firms in each sector-year, which have been omitted from the table. $D_{t}$ is a dummy indicating the period following the year reported on the column header and $E_{j}$ is the enforcement index at state-level. These are interacted with category dummies: Central, Capacity, ID and State. The omitted category is "No EIA" (non-polluting firms).

Table A.9: Incidence of formality by sector in 1999

\begin{tabular}{|c|c|c|c|c|}
\hline & $\underset{\%}{\text { Formal Firms }}$ & Formal $\underset{\%}{\text { Employees }}$ & $\underset{\%}{\text { Formal Output }}$ & Group \\
\hline \multicolumn{5}{|c|}{ High degree of informality } \\
\hline Beverages, tobacco & 0.1 & 12.7 & 74.1 & Capacity \\
\hline Wood, furniture, fixtures & 0.1 & 0.9 & 15.6 & NoEIA \\
\hline Textile products & 0.2 & 5.9 & 58 & State \\
\hline Other & 0.3 & 7.3 & 59.4 & - \\
\hline Wool, silk, synthetic textiles & 0.7 & 16.1 & 73.8 & State \\
\hline Cotton textiles & 0.8 & 22.7 & 83.4 & NoEIA \\
\hline Food products & 0.8 & 17.7 & 76.9 & ID/NoEIA \\
\hline Jute, vegetable fibre & 0.8 & 50.3 & 98.2 & State \\
\hline Leather & 0.9 & 22.4 & 72.4 & ID \\
\hline \multicolumn{5}{|c|}{ Low degree of informality } \\
\hline Metal products and parts & $\begin{array}{l}1.2 \\
1.4\end{array}$ & $\begin{array}{l}14.4 \\
13.4\end{array}$ & $\begin{array}{l}62.1 \\
69.6\end{array}$ & $\begin{array}{c}\text { Capacity } \\
\text { Central/Capacity }\end{array}$ \\
\hline Paper, printing, finishing & 2.5 & 27.6 & 78.3 & State \\
\hline Basic chemicals & 4.1 & 58.4 & 95.6 & District/Central \\
\hline Machinery and equipment & 5.3 & 50.6 & 86.1 & NoEIA \\
\hline Rubber, plastic, petroleum, coal & 5.6 & 46.4 & 88.1 & ID \\
\hline Electrical machinery & 6.3 & 53.5 & 59 & NoEIA \\
\hline Transport equipment & 10.3 & 73.1 & 94.2 & NoEIA \\
\hline Basic metal and alloys & 14.3 & 82.6 & 94.5 & Capacity \\
\hline
\end{tabular}

These estimations are taken from Nataraj (2010), page 22. Original source: Annual Survey of Industries (ASI) and Unorganised Manufacture Survey (UMS) 